\title{
Effect of therapeutic ultrasound on the mechanical and
} biological properties of fibroblasts

Rosy P. Cárdenas-Sandoval ${ }^{1,2 *}$, Homero F. Pastrana-Rendón ${ }^{3,8}$, Alba G. Ávila-Bernal ${ }^{3}$, Angélica M. Ramírez-Martínez ${ }^{4}$, Myriam L. Navarrete-Jimenez ${ }^{5}$, Alejandro O. Ondo-Mendez ${ }^{6}$, Diego A. Garzón-Alvarado 2,7

${ }^{1}$ Rehabilitation Science Research Group, School of Medicine and Health Sciences, Universidad del Rosario; Bogotá, Colombia, 111221

${ }^{2}$ Organ and Tissue Mechanobiology Reasearch Group. Biotechnology Institute, Universidad Nacional de Colombia; Bogotá, Colombia, 111321

${ }^{3}$ Microelectronics Research Center. Department of Electrical and Electronic Engineering, Universidad de los Andes; Bogotá, Colombia, 111711

${ }^{4}$ Department of Biomedical Engineering, Universidad Militar Nueva Granada, sede Campus; Cajicá, Colombia, 250247

${ }^{5}$ Department of Microbiology, Faculty of Medicine, Universidad Nacional de Colombia; Bogotá, Colombia, 111321

${ }^{6}$ Clinical Research Group, School of Medicine and Health Sciences, Universidad del Rosario; Bogotá, Colombia, 111221

${ }^{7}$ Department of Mechanical and Mechatronics Engineering, Universidad Nacional de Colombia; Bogotá, Colombia, 111321 
bioRxiv preprint doi: https://doi.org/10.1101/2021.11.22.469508; this version posted November 22, 2021. The copyright holder for this preprint (which was not certified by peer review) is the author/funder, who has granted bioRxiv a license to display the preprint in perpetuity. It is made available under aCC-BY 4.0 International license.

${ }^{8}$ Currently at Doctorado en Ciencias de la Salud, Universidad Antonio Nariño, Bogotá, Colombia, 111821

*Corresponding author. Email: rosy.cardenas@urosario.edu.co 

to improve the regenerative and remodeling stages of the wound healing process. Using a multidisciplinary approach, we applied ultrasound doses of 1.0 and $2.0 \mathrm{~W} / \mathrm{cm}^{2}$ at $1 \mathrm{MHz}$ frequency for five days on ligament fibroblasts. Atomic force microscopy showed a decrease in cell elastic modulus for both doses, but the treated cells were still viable based on flow cytometry. Finite element method analysis exhibited visible cytoskeleton displacements and decreased harmonics in treated cells. Colorimetric assay revealed increased cell proliferation, while scratch assay showed increased migration at low doses. An increase in collagen and fibronectin was detected by enzymelinked immunoassay at high doses, and $\beta$-actin expression for both treatments was visualized through immunofluorescence imaging. Both doses of ultrasound altered the fibroblast mechanical properties due to cytoskeletal reorganization and enhanced the early and late stages of cell repair. 


\section{Introduction}

Therapeutic ultrasound produces sound waves to create vibrations that exert forces on cells and stimulate the regenerative and remodeling stages coordinated by fibroblasts during the wound healing process [1-3]. Nevertheless, the exact dose of ultrasound that may affect the ligament fibroblast elastic modulus and harmonic vibration to improve the regenerative and remodeling stages remain largely elusive. The elastic modulus of cells is a biomarker that determines several biological responses such as communication with the environment, cell death, aging, and cellular motility [4-6]. It may also influence the harmonic vibration (i.e., the natural frequencies of vibration of the cell structure) [7], which is the rate at which the structure oscillates at a point of balance without being affected by an external force [8].

Therapeutic ultrasound generates a micro-massaging effect caused by compression and negative pressure resulting from micro-vibration and cavitation [9-13]. Cellular transmembrane receptors such as integrins and cadherins detect these forces, and consequently, external stimuli are conducted rapidly along cytoskeleton filaments and absorbed at reserved edges in the cytoplasm and nucleus, modifying the cellular genome activities by increasing collagen synthesis and activating the mitotic activity of cells [14-16].

Cells react to external physical stimuli caused by ultrasound by altering their cytoskeleton, which is the structure responsible for regulating the mechanical behavior of cells. The cytoskeleton maintains the cell shape, responds to external mechanical cues, exerts forces, and produces motion $[13,17,18]$. It transduces the mechanical signal and converts it into a biological response associated with the wound healing process. This is evidenced by measuring changes in the cell mechanical properties $[4-6,17,19-22]$. 
The mechanical and biological effects of applying conventional ultrasound doses of $0.1-3 \mathrm{~W} / \mathrm{cm}^{2}$ spatial average temporal average intensity (SATA) at 1-3 MHz frequency to ligament fibroblasts remains unclear [23]. Evidence so far has shown contradictory results: on the one hand, when therapeutic ultrasound is applied at conventional frequencies [9-12], there is no resonance effect. For example, when applying therapeutic ultrasound at $1 \mathrm{MHz}$ and low intensities (less than 1.0 $\mathrm{W} / \mathrm{cm}^{2}$ ), cell proliferation and extracellular matrix (ECM) improve on dermal and periodontal ligament fibroblasts [23-27]. Moreover, this high frequency may modulate cell cytoskeleton organization [28,29] which in turn stimulates cell migration [30]. On the other hand, when applying ultrasound at low frequencies in the kilohertz range, a resonance effect occurs, in which the integrity of the cell structure may be compromised because of the oscillation at such frequencies that coincide with the harmonic vibration of the cell [7,31-33]. For example, when applying ultrasound at frequencies between $550 \mathrm{kHz}$ and $650 \mathrm{kHz}$, cell death increases and cell proliferation decreases in breast cancer cells [34].

The effects of conventional doses of therapeutic ultrasound used in rehabilitation [23] on the elastic modulus and harmonic vibration (mechanical properties), as well as on the viability, proliferation, migration, and synthesis of the ECM (type I collagen, type III collagen, and fibronectin) and $\beta$ actin expression (biological properties) of ligament fibroblasts in joints remain uncertain [35-38]. The controversy concerning the contradictory results of ultrasound and the lack of evidence motivated us to measure and demonstrate that the mechanical and biological properties can be modulated by the reorganization of the ligament fibroblast cytoskeleton after applying conventional doses of therapeutic ultrasound.

Therapeutic ultrasound modifies the cell elastic modulus and its harmonic vibration, while cells reorganize their cytoskeleton structure without resonance or harmful effects. It also improves the regenerative and remodeling functions of ligament fibroblasts. This complex effect cannot be 
evaluated by clinical assessment of a physiotherapist. Thus, we applied a multidisciplinary approach that integrates in vitro and computational techniques to assess the effects on the mechanical and biological responses of ligament fibroblasts of joints by applying two intensities of conventional therapeutic ultrasound, namely, a low dose of $1.0 \mathrm{~W} / \mathrm{cm}^{2}$ and a high dose of 2.0 $\mathrm{W} / \mathrm{cm}^{2}$, both at a frequency of $1 \mathrm{MHz}$. Furthermore, we determined the specific ultrasound dose required to improve the regenerative (early) and remodeling (late) phases of the ligament fibroblast healing process.

\section{Materials and Methods}

An explant technique was used to obtain ligament fibroblasts. The protocol of ultrasound therapy applied to cultured cells followed the standard clinical guidelines for ligament treatment. We evaluated the effects of therapeutic ultrasound on the mechanical properties of ligament fibroblasts by measuring their elastic modulus using atomic force microscopy (AFM), and the harmonics of the natural frequencies of vibration of the ligament fibroblast cytoskeleton using a finite element method FEM analysis. Moreover, we evaluated the biological properties of ligament fibroblasts by performing the following experiments: cell viability using flow cytometry, fibroblast cell proliferation by a colorimetric assay), cell migration using scratch assay, ECM synthesis by enzyme-linked immunoassay (ELISA), and $\beta$-actin expression through immunofluorescence imaging. A diagram of the methodology is shown in Fig 1.

Fig 1. Diagram of the methodology. (1) Ligament explant, (2) ultrasound stimulation, (3) measurement of mechanical and biological parameters, and (4) statistical analysis. 


\section{Ligament fibroblast explant}

Fibroblast cells were obtained using an explant technique from the lateral collateral ligaments (LCLs) of both knees of one adult male Wistar rat, as depicted in Fig 2A-B, following a previously described protocol [39]. The experiments were performed according to the international regulations of laboratory animals. Moreover, the animal studies and research protocols were approved by a local ethics committee (Protocol Number:FC-13-01082016). The LCLs were maintained under aseptic conditions in a 1:1 mixture of Dulbecco's modified Eagle medium and nutrient mixture F-12 (DMEM/F12; DF-041-B; Merck Millipore) supplemented with $1 \%$ antibiotic/antifungal (15240062; Gibco) and 10\% fetal bovine serum (FBS; 12657029 ; Gibco). Dissection was performed with the aid of a scalpel to cut the femoral and fibular insertions. The LCLs were placed into T-25 culture flasks containing a sterile supplemented culture medium, as exhibited in Fig 2C. The culture medium was changed every $48 \mathrm{~h}$.

The flasks were incubated at $37^{\circ} \mathrm{C}$ in a humidified atmosphere containing $5 \% \mathrm{CO}_{2}$. After 15 days, the monolayer cultures became confluent, and the tissues were removed from the flasks. Explanted cells were washed with Hank's balanced salt solution (14065056; Gibco), detached using $0.025 \%$ trypsin (15400054; Gibco) for $5 \mathrm{~min}$, centrifuged at $287 \times \mathrm{g}$ for $5 \mathrm{~min}$, and subcultured for subsequent experiments. The remaining cells were cryopreserved in a mixture of 10\% DMEM/F12, 80\% FBS, and 10\% dimethyl sulfoxide.

Fig 2. Ligament fibroblast explant. (A) Adult male Wistar rat; (B) lateral collateral ligament (LCL); (C) ligament tissues cultured in a T-25 culture flask. 
To ensure that the cells explanted from the ligaments corresponded to fibroblasts, their nuclei and bodies were highlighted using hematoxylin-eosin staining (H\&E) and microscopic observation [40]. We followed the laboratory protocol described by Spitalnik [41].

\section{Pulsed ultrasound intensity and application time}

We applied energies of 1.5 and $5.0 \mathrm{~J} / \mathrm{cm}^{2}$ for five days to the two treatment groups that we designed. These energies correspond to $5 \%$ and $17 \%$ of the $30 \mathrm{~J} / \mathrm{cm}^{2}$ applied in human therapy [42-46]. Treatment Group A received $1.0 \mathrm{~W} / \mathrm{cm}^{2}$ (low dose), whereas treatment Group B received $2.0 \mathrm{~W} / \mathrm{cm}^{2}$ (high dose) of the maximum intensity. The SATA values were $0.5 \mathrm{~W} / \mathrm{cm}^{2}$ and $1.0 \mathrm{~W} / \mathrm{cm}^{2}$ for treatment Groups A and B, respectively. A layer of sound wave transmission gel was applied over the transducer, and the culture plates were then placed over the ultrasound device. Control cells were processed in the same way but without turning the device on. For both treatments, a standard "J-Style" (JC-2902) ultrasound device was used following the standard clinical procedures for ligament therapy [47].

Based on the ultrasound parameters and the surface area of the plate culture, the application time $t$ of the ultrasound was calculated using the potency equation of energy transmission $[11,12,48]$, expressed as Equation 1.

Here, $e$ is the energy per square centimeter [49], $I$ is the transducer intensity, $a_{t}$ is the effective radiated area, $D$ is the duty cycle, and $a_{c}$ is the culture area. The application time for each culture 

experiment as that in the treatment groups with no ultrasound.

Table 1. Surface area and application time of ultrasound in each treatment group.

\begin{tabular}{|c|c|c|c|}
\hline \multirow[b]{2}{*}{ Experiment variable } & \multirow{2}{*}{$\begin{array}{l}\text { Surface area of } \\
\text { plate culture } \\
\left(\mathrm{cm}^{2}\right)\end{array}$} & \multicolumn{2}{|c|}{ Ultrasound application time (s) } \\
\hline & & $\begin{array}{l}\text { Group A (low } \\
\text { dose: } 1.0 \\
\left.\mathrm{~W} / \mathrm{cm}^{2}\right)\end{array}$ & $\begin{array}{l}\text { Group B (high } \\
\text { dose: } 2.0 \\
\left.\mathrm{~W} / \mathrm{cm}^{2}\right)\end{array}$ \\
\hline $\begin{array}{l}\text { Elastic modulus } \\
\text { Petri dish }\end{array}$ & 11.78 & 7 & 12 \\
\hline $\begin{array}{l}\text { Viability } \\
\text { 6-well plate }\end{array}$ & 3.5 & 2.1 & 3.5 \\
\hline $\begin{array}{l}\text { Cell } \\
\text { proliferation } \\
\text { 96-well plate } \\
\text { (groups of } 9 \\
\text { wells) }\end{array}$ & 5 & 3 & 5 \\
\hline $\begin{array}{l}\text { Migration } \\
\text { 12-well plate }\end{array}$ & 109.9 & 66 & 110 \\
\hline $\begin{array}{l}\text { ECM synthesis } \\
\text { 6-well plate }\end{array}$ & 3.5 & 2.1 & 3.5 \\
\hline
\end{tabular}




\section{Fibroblast elastic modulus by AFM}

Fibroblasts $\left(3.5 \times 10^{2}\right.$ cells from each treatment group $)$ were cultured in Petri dishes $(3.5 \mathrm{~cm}$ diameter) and reached $20-40 \%$ confluency on the $6^{\text {th }}$ day. We measured the elastic modulus of proliferating viable cells maintained in DMEM/F12 within 2-3 h. Changes in the cell elastic modulus were monitored using AFM (MFP3D-Bio AFM system, Asylum Research, Santa Barbara, CA) [50,51].

Soft cantilevers T R400P B (Olympus, Japan) with a nominal spring constant of $0.09 \mathrm{~N} / \mathrm{m}$, a tip radius of $42 \mathrm{~nm}$, and a half-opening angle of $35^{\circ}$ were employed. The relative trigger force was $2 \mathrm{nN}$. The elastic modulus was estimated as a function of the position on the cell using the force-volume technique by measuring the cantilever deflection. We used a video microscope to position the AFM tip at precise locations over the cell surface. The probe moved up and down, simultaneously registering the force curve and cell topography at each pixel of the surface. We obtained force-volume images with a resolution of $20 \times 20$ pixels within $30 \times 30 \mu \mathrm{m}^{2}$ scan areas for 10 cells per group. The approximate acquisition time per image was $15 \mathrm{~min}$.

The numbers of effective measurements performed for Groups A, B, and C were 863, 866, and 338 indentations, respectively. We used a larger sample to better calculate the average values of the elastic modulus and avoid errors associated with the indentation depth. Force curves determined from a relative area above the whole cell enabled the comparison of induced changes to a constant force. Because the elastic modulus ( calculated using the Sneddon model) may create a substrate effect, which is a source of error, due to sharp probe indentation producing a larger depth [52], we used an asymptotical correction model to nullify the bottom substrate effect for rigid cone indenting [53], as indicated in Equation 2. 


$$
F_{e}=\frac{8 E}{3 \pi} \tan (\theta) \delta^{2}\left\{1+C \frac{4}{\pi^{2}} \frac{\delta}{h}+C^{2} \frac{20}{\pi^{4}} \frac{\delta^{2}}{h^{2}}+0\left(\frac{\delta^{3}}{h^{3}}\right)\right\}
$$
$\tan (\theta)$ [53]. Refer to the supporting information (S1 File) for additional details.

\section{Harmonic vibration and modal analysis by finite element method} predominantly determines cell mechanics and its response to external stimuli. Without the network of filaments that compose the cytoskeleton (actin, intermediate filaments, and microtubules),

we performed an FEM analysis to simulate the harmonics of the natural frequencies of vibration of the ligament fibroblast cytoskeleton using the eigenvalue extraction method Lanczos (ABAQUS/CAE 6.12.3 software). Modal analysis was used to predict the $50^{\text {th }}$ natural frequencies and eigenforms of the cytoskeleton. A three-dimensional (3D) octahedron tensegrity model with 12 coordinates and 30 beam elements represented the cytoskeleton (Fig 3) [56]. As the cytoskeleton is composed of a protein network of filaments, the tensegrity structure mimics 12 actin filament beams, 12 intermediate filament beams, and microtubule beams. The actin filaments were located in the cortex, the intermediate filaments in the middle, and the microtubules were in the center of the structure $[57,58]$. 
Fig 3. Three-dimensional octahedron tensegrity model. Ligament fibroblast cytoskeleton tensegrity structure.

The cell elastic modulus measured by AFM may elucidate the changes in cytoskeleton elasticity [50,59]. Hence, the elastic modulus median and the mean height values for treated cells and the control group were taken from the AFM results as input parameters for the tensegrity structure to calculate the harmonic vibration and perform the modal analysis for every cytoskeleton

Table 2. Cytoskeleton filament material characteristics. The elastic modulus and height were taken from the AFM results obtained for both treatment groups and the control group. The Poisson's ratio, length, and beam radius were taken from the literature.

\begin{tabular}{|c|c|c|c|c|}
\hline & Actin & $\begin{array}{l}\text { Intermediate } \\
\text { Filaments }\end{array}$ & Microtubules \\
\hline \multirow{3}{*}{$\begin{array}{l}\text { Median elastic } \\
\text { modulus }(\mathrm{Pa}) \\
\text { from AFM }\end{array}$} & $1.0 \mathrm{~W} / \mathrm{cm}^{2}$ & \multicolumn{3}{|c|}{1085} \\
\hline & $2.0 \mathrm{~W} / \mathrm{cm}^{2}$ & \multicolumn{3}{|c|}{970} \\
\hline & Control & \multicolumn{3}{|c|}{1399} \\
\hline Mean height & $1.0 \mathrm{~W} / \mathrm{cm}^{2}$ & \multicolumn{3}{|c|}{4.6} \\
\hline$(\mu \mathrm{m})$ from & $2.0 \mathrm{~W} / \mathrm{cm}^{2}$ & \multicolumn{3}{|c|}{3.1} \\
\hline AFM & Control & \multicolumn{3}{|c|}{2.7} \\
\hline
\end{tabular}




\begin{tabular}{|l|c|c|c|}
\hline $\begin{array}{l}\text { Length of the contact radius } \\
(\mu \mathrm{m})\end{array}$ & \multicolumn{2}{|c|}{11.2} \\
\hline Poisson's ratio & $0.4 \pm 0.08$ & $0.5 \pm 0.05$ & $0.36 \pm 0.06$ \\
\hline Beam radius $(\mathrm{m})$ & $2 \times 10^{-9}[63]$ & $5 \times 10^{-6}[62]$ & $8 \times 10^{-9}[63]$ \\
\hline
\end{tabular}

The units were converted to microscale. The cytoskeleton filaments were considered isotropic and elastic because the cells had small deformations of $2-8 \%$ [57,63-65]. The beam length of the contact radius in the tensegrity structure was $11.2 \mu \mathrm{m}$ [63]. The filament density was $1.15 \times 10^{-6} \mu \mathrm{g} / \mu \mathrm{m}^{3}[7]$. The initial boundary conditions were imposed on the three base nodes of the tensegrity structure [63]. The three receptor nodes represented the focal adhesion of the cell to the ECM because ligament fibroblasts are adherent cells and are dependent on the actin cytoskeleton [66]. They were constrained for three degrees of freedom $(\mathrm{U} 1=\mathrm{U} 2=\mathrm{U} 3=\mathrm{UR} 1=$ $\mathrm{UR2}=\mathrm{UR} 3=0)$

The height values ( $\mathrm{Y}$ axes) for each octahedron structure were taken from the mean values obtained in the AFM force-volume topography maps, and the $\mathrm{X}$ and $\mathrm{Z}$ axes values were taken from the literature to comply with the spread shape of an adherent cell $[63,67]$. propidium iodide (PI- ab14083) were used to quantitate non-apoptotic cells, cells in early apoptosis, necrotic cells, and cells in late apoptosis post-treatment [68]. Samples were analyzed using a flow cytometer (BD FACS Canto II) with a solid-state (L1) laser (488 nm excitation line, 234 air-cooled, $20 \mathrm{~mW}$ solid state). 
Fibroblasts $\left(2.84 \times 10^{4}\right.$ cells per group) were cultured in a six-well plate until $100 \%$ confluency was attained on the $6^{\text {th }}$ day. One well was stained with Annexin V-FITC, another with PI, and the third with both. The other wells served as controls. The samples were placed in cytometry tubes and diluted in $300 \mu \mathrm{L}$ of the culture medium. Each well corresponded to a specific

An $\quad$ MTS

tetrazolium

assay

(MTS=3-(4,5-dimethylthiazol-2-yl)-5-(3carboxymethoxyphenyl)-2-(4-sulfophenil)-2H-tetrazolium, inner salt) [70] measures the interaction between viable cells (mitochondrial enzymatic activity) and phenazine methosulfate. This interaction generates a formazan product that is soluble in culture media to count the increased number of viable fibroblast cells [71-73]. We quantified the number of viable fibroblast cells in proliferation on the $1^{\text {st }}$ and $3^{\text {rd }}$ day of the stimulation period and on the $6^{\text {th }}$ day after the stimulation period.

Ligament fibroblasts from each treatment group were cultured in a single 96 -well plate $(4 \times$ $10^{1}$ cells/well) containing $200 \mu \mathrm{L}$ of culture medium until $100 \%$ confluency was achieved on the $6^{\text {th }}$ day. We divided the $96-$ well plate into six groups of nine wells $(3 \times 3$ wells $)$. The remaining wells served as blank controls, in which only a culture medium with no cells was added. Twenty microliters of reagent was added directly to each well plate following the instructions of the MTS Cell Proliferation Assay Kit (colorimetric ab197010, abcam ${ }^{\circledR}$ ). The culture plate was incubated for $3 \mathrm{~h}$ at $37^{\circ} \mathrm{C}$ in a humidified atmosphere containing $5 \% \mathrm{CO}_{2}$. Absorbance at $490 \mathrm{~nm}$ was 
measured using a microplate reader. The mean absorbance was calculated by subtracting the absorbance of the treatment groups from the absorbance of the blank controls.

\section{Fibroblast cell migration measured by scratch assay}

We seeded $50 \times 10^{3}$ cells in a 12 -well plate to fully cover the surface after finishing the treatment ( $6^{\text {th }}$ day). We used an in vitro scratch assay as described by Liang et al. to measure

\section{Fibroblast ECM synthesis: type I collagen, type III collagen, and}

\section{fibronectin measured by ELISA}

Ligament fibroblasts from both treatment groups and the control group were cultured in three separate six-well plates $\left(1.8 \times 10^{3}\right.$ cells/well $)$ containing $1 \mathrm{~mL}$ of culture medium until $100 \%$ confluency was reached on the $6^{\text {th }}$ day. Only three of the six wells were seeded in the third plate 
where control Group C was cultured. We used ELISA to measure the protein concentration of type I collagen, type III collagen, and fibronectin in ligament fibroblast supernatants on the $6^{\text {th }}$ and $10^{\text {th }}$ day after the stimulation period $[75,76]$. On the $10^{\text {th }}$ day, we evaluated the protein concentration because type I collagen requires more days to be released than type III collagen. Between the $6^{\text {th }}$ and the $10^{\text {th }}$ day, the cells were maintained under aseptic conditions in a 1:1 mixture of DMEM/F12 (DF-041-B; Merck Millipore) supplemented with 1\% antibiotic/antifungal (15240062; Gibco) and 10\% FBS (12657029; Gibco). All cell culture supernatant samples $(1 \mathrm{~mL})$ were collected on the $6^{\text {th }}$ and $10^{\text {th }}$ day, then stored at $4^{\circ} \mathrm{C}$ and assayed within 7 days.

We used rat collagen type I (E-EL-R0233), rat collagen type III (E-EL-R0235), and rat fibronectin (E-EL-R0578) Elabscience ${ }^{\circledR}$ ELISA kits. Eight serial dilutions were performed using the reference standard from the kit until the protein reached $20 \mathrm{ng} / \mathrm{mL}$. Then, we collected a duplicate sample of each dilution, and 16 samples were transferred to a 96-well ELISA plate. The culture medium (100 $\mu \mathrm{L} /$ well) from both treatment ( 6 samples) and control (3 samples) groups on the $6^{\text {th }}$ and $10^{\text {th }}$ day was aspirated and transferred to a 96 -well ELISA plate (a total of 30 samples). We added a duplicate blank control $(100 \mu \mathrm{L} /$ well of the standard working solution of the substratum) and a duplicate negative control $(100 \mu \mathrm{L} /$ well of the supplemented cell culture medium and no cells) to the 96-well ELISA plate.

The readings of the wells that contained the samples of the treatment and control groups, blanks, and negatives were obtained using a microplate reader (absorbance of $450 \mathrm{~nm}$ ). The reading of the negative control was subtracted from the readings of the treatment and control groups to obtain the final optical density (OD) of the samples. A curvilinear regression line was constructed using the standard to calculate the protein concentration. In total, six samples from the treatment groups and three from the control group were measured. When the concentrations were less than the lowest value of the standard curve, the protein concentration $(\mathrm{ng} / \mathrm{mL})$ was not detected 

in one sample from treatment Group A on the $10^{\text {th }}$ day, in three samples of treatment Group B on the $6^{\text {th }}$ day, and in two samples of control Group $C$ on the $6^{\text {th }}$ day.

\section{$\beta$-actin expression measured by immunofluorescence imaging}

To demonstrate that ligament fibroblasts activate their cytoskeleton after treatment, we assessed the presence of $\beta$-actin filaments, an essential component of the fibroblast cytoskeleton [77]. Treated ligament fibroblasts cultured on coverslips were fixed with $4 \%$ formaldehyde, permeabilized using $0.1 \%$ Triton, stained with a monoclonal antibody (Invitrogen,15G5A11/E2) against rat $\beta$-actin at a dilution of 1:2000, and incubated overnight at $4^{\circ} \mathrm{C}$. Afterward, the cells were incubated with 488-conjugated goat anti-mouse $\operatorname{IgG}$ secondary antibody (Invitrogen, A32723) at a dilution of 1:1000 conjugated with Invitrogen Alexa Fluor ${ }^{\circledR}$. Finally, nuclei were stained with Hoechst 33342. Images were taken on a cell imaging reader microscopy (Cytation 3 cell imager multi-mode reader; Biotek).

We calculated the shortening area of $\beta$-actin in each image corresponding to each treatment group. Then, we analyzed three images per group using the immunohistochemistry (IHC) image analysis toolbox plugin in ImageJ software version 1.50i 3 for Windows (developed by Wayne Rasband, National Institutes of Health, USA, http://imagej.nih.gov/ij) by following the live-cell actin analysis proposed by Hoyle et al. [66]. We trained the algorithm by recording five color pixels of the images to detect the green color of the $\beta$-actin filaments stained with Alexa Fluor ${ }^{\circledR}$. The statistical color detection model was then automatically calculated. A total of $29 \pm 1$ cells per image were analyzed per group. After generating the detected green area in each image, we calculated the total area of the $\beta$-actin filaments using the following steps. First, we converted the read-green-blue (RGB) image into an 8-bit grayscale. Then, we adjusted the threshold to select the entire $\beta$-actin green area and converted it to black. (Additional details can be found in the 
supporting information (S2 File)). Finally, we run the particle analysis by defining the size (zero to infinity) and circularity $(0.0$ to 1.0$)$. The results were obtained in micrometers.

\section{Statistical analyses}

Statistical analyses were conducted using BioVinci software version 2.8.5 for Windows (BioTuring Inc., San Diego California USA, www.bioturing.com), a software environment for data visualization, analysis, and machine learning in the life sciences. All data were representatives of at least three independent experiments. Normality was assessed using the Shapiro-Wilk test, Pearson chi-square test, one-sample Kolmogorov-Smirnov test, and Jarque-Bera test. Because the data were not normally distributed, the medians (elastic modulus and ECM synthesis) and means (fibroblast cell proliferation and migration) were compared across groups using a nonparametric multiple comparison Kruskal-Wallis test. The data were presented as means and standard errors of the means (SEMs) for the cell proliferation, cell migration, and $\beta$-actin area. Then, they were shown as a boxplot with medians for elastic modulus, harmonics, and ECM synthesis. Statistical significance was assumed at $\mathrm{P}<0.05$.

\section{Results}

\section{Ligament fibroblasts}

The ligament fibroblasts were motile around the explanted tissue (Fig 4A) and then adhered to the flasks where they proliferated. The typical characteristics of fibroblasts (Fig 4B), namely, adherence; presence of nucleus and body; flat, elongated, and triangular shape; and linkage between cells, were evident [78]. 
Fig 4. Ligament fibroblasts. (A) After 15 days, the ligament fibroblasts were motile around the ligament explant. (B) Adherent cells were stained with H\&E.

\section{Effect of ultrasound treatment on ligament fibroblast structure}

The AFM revealed that the median elastic modulus of the treated ligament fibroblasts decreased by $22 \%$ for the low dose $\left(1.0 \mathrm{~W} / \mathrm{cm}^{2}\right)$ and $31 \%$ for the high dose $\left(2.0 \mathrm{~W} / \mathrm{cm}^{2}\right)$ compared to that of the control group. We found significant differences among the groups $\left(* * * \mathrm{P}=0.00001 \times 10^{-6}\right.$; Fig 5A). Additionally, the ligament fibroblast topography through 3D force-volume maps showed darker areas for the treated cells than those of the control group (Fig 5B). This means that the application of low and high doses of therapeutic ultrasound softens the ligament fibroblast structure. Because the cell structure is mainly provided by the cytoskeleton, we inferred that both treatments caused a reorganization of the cytoskeleton through $\beta$-actin activation, which could produce cell biological responses such as proliferation, migration, and ECM synthesis, as will be demonstrated in the next sections.

\section{7}

Fig 5. Softening of ligament fibroblast structure due to low and high doses of ultrasound. (A) Boxplot showing medians with whiskers from minimum to maximum values. (B) 3D forcevolume topography maps from AFM results. 


\section{Effect of ultrasound treatment on harmonic vibration}

376 Using the FEM, we calculated until the $50^{\text {th }}$ harmonic of the natural frequency of vibration and 377 the $50^{\text {th }}$ eigenform (mode of vibration) for each cytoskeleton structure. We found similar 378 displacements of the ligament fibroblast cytoskeleton for the treated cells but a different 379 displacement for the control group. An example of this finding is illustrated in the $5^{\text {th }}$ mode of 380 vibration (Fig 6A). The displacements for all groups are featured in the animation (S3 Movie). In 381 terms of the natural frequencies of vibration, higher frequencies were predicted when the 382 cytoskeleton filaments had a higher elastic modulus (control group), reaching a maximum 383 vibration frequency of $4.1 \times 10^{9} \mathrm{~Hz}$ in the $50^{\text {th }}$ vibration mode. When the cytoskeleton filaments 384 had the elastic modulus of treatment Groups A and B from the AFM results, the vibration 385 frequencies decreased up to a maximum of $3.3 \times 10^{9} \mathrm{~Hz}$ in the $50^{\text {th }}$ vibration mode for both 386 structures (Fig 6B). The median of the $50^{\text {th }}$ harmonic of the natural frequencies of vibration of 387 the treated ligament fibroblasts decreased by $13 \%$ for the low dose $\left(1.0 \mathrm{~W} / \mathrm{cm}^{2}\right)$ and $17 \%$ for the 388 high dose $\left(2.0 \mathrm{~W} / \mathrm{cm}^{2}\right)$ compared to that of the control group. Nevertheless, there was no 389 statistically significant difference among the groups $(\mathrm{P}=0.514)$. It means that harmonic of the 390 natural frequencies of vibration are not dependent on the elastic modulus decreased by the 391 dosage of ultrasound treatment. whiskers from minimum to maximum values. 


\title{
Effect of ultrasound treatment on viability of ligament fibroblasts
}

\author{
399 Histograms from the cell death assays indicated the number of cells stained with Annexin V-FITC \\ 400 and/or PI (Fig 7A). Flow cytometry showed that most cells were viable in the treatment and control \\ 401 groups (Fig 7B). The number of events collected was 10,000. The results showed that cell viability \\ 402 slightly decreased by $1 \%$ for the low dose $\left(1.0 \mathrm{~W} / \mathrm{cm}^{2}\right)$ and $10 \%$ for the high dose $\left(2.0 \mathrm{~W} / \mathrm{cm}^{2}\right)$ \\ 403 compared to that of the control group.
}

Fig 7. Negligible effect of low and high doses of ultrasound on viability of ligament fibroblasts. (A) Histogram and dot plot of cell viability assay using Annexin V-FITC and cationic marker PI. Quartile 1: necrotic cells; Q2: late apoptotic cells; Q3: viable cells; and Q4: early apoptotic cells. (B) Bar plot of the mean number of events for each quartile of the flow cytometry data.

\section{Effect of ultrasound on fibroblast cell proliferation in early}

The MTS assay showed that on the $1^{\text {st }}$ day of culture, cell proliferation increased by $25 \%$ for the low dose $\left(1.0 \mathrm{~W} / \mathrm{cm}^{2}\right)$ compared to that of the control group. On the $3^{\text {rd }}$ day of culture, the same experiment showed that cell proliferation decreased by $11 \%$ for the low dose and $9 \%$ for the high dose $\left(2.0 \mathrm{~W} / \mathrm{cm}^{2}\right)$ compared to that of the control group. On the $6^{\text {th }}$ day of culture $\left(1^{\text {st }}\right.$ post-treatment day), cell proliferation increased by $10 \%$ for the low dose but decreased by $13 \%$ for the high dose 
compared to that of the control group. We found significant differences among the groups $(* \mathrm{P}=$ 0.041; Fig 8). We demonstrated that a low ultrasound dose increases the cell proliferation of ligament fibroblasts on the $6^{\text {th }}$ day after the stimulation period.

\section{Fig 8. Increase in fibroblast cell proliferation in early treatment due to low dose of}

ultrasound. The mean of cell number in proliferation of ligament fibroblasts is higher for the low dose on the $6^{\text {th }}$ day after treatment. Error bars indicate SEMs.

\section{Effect of therapeutic ultrasound on fibroblast cell migration in early}

\section{treatment}

The scratch assay (Fig 9A) showed that the mean migration length of ligament fibroblasts increased by $4 \%$ for the low dose $\left(1.0 \mathrm{~W} / \mathrm{cm}^{2}\right)$ and decreased by $11 \%$ for the high dose $\left(2.0 \mathrm{~W} / \mathrm{cm}^{2}\right)$ compared to that of the control group after $24 \mathrm{~h}$. We found significant differences among the groups $\left(* * * \mathrm{P}=0.00003 \times 10^{-4}\right.$; Fig $\left.9 \mathrm{~B}\right)$. A total of 102, 102, and 107 images were obtained for the treatment groups (A and B) and control group (C), respectively. Twenty images from Group A were excluded because of their poor quality. We analyzed 494 measurements from Group A, 613 from Group B, and 641 from Group C.

Fig 9. Effect of therapeutic ultrasound on fibroblast cell migration in early treatment. (A) Scratch assay results for the low dose treatment Group A $\left(1.0 \mathrm{~W} / \mathrm{cm}^{2}\right)$, high dose treatment Group 


\author{
$440 \quad$ B $\left(2.0 \mathrm{~W} / \mathrm{cm}^{2}\right)$, and control Group C. (B) Mean migration length $(\mu \mathrm{m}) 24 \mathrm{~h}$ after treatment. Error \\ 441 bars represent SEMs.
}

\title{
Effect of therapeutic ultrasound on the OD of ECM: type I collagen,
} type III collagen, and fibronectin synthesis for early and late

\section{treatments}

Therapeutic ultrasound significantly increased the median OD among groups of type I collagen $(* \mathrm{P}=0.03)$, type III collagen $(* \mathrm{P}=0.02)$, and fibronectin $(* * \mathrm{P}=0.003)$ on the $6^{\text {th }}$ day. Compared to the control group on the $6^{\text {th }}$ day after the stimulation period, the low dose of ultrasound increased the OD of the three proteins: type I collagen by $27 \%$; type III collagen by $59 \%$; and fibronectin by $32 \%$. In contrast, compared to the control group on the $6^{\text {th }}$ day after the stimulation period, the high dose of ultrasound increased the OD of both collagens (type I collagen by $57 \%$; type III collagen by $79 \%$ ) but decreased fibronectin by $83 \%$. Compared to the control group on the $10^{\text {th }}$ day after the stimulation period, the low dose of ultrasound increased the OD of both collagens (type I collagen by $8 \%$; type III collagen by $37 \%$ ) but decreased fibronectin by $57 \%$. In contrast, compared to the control group on the $10^{\text {th }}$ day after the stimulation period, the high dose of ultrasound increased the OD of the three proteins: type I collagen by $32 \%$; type III collagen by $51 \%$; and fibronectin by $31 \%$ (Fig 10$)$. 


\section{Fig 10. Increase in the optical density (OD) of extracellular matrix (ECM) for early and late}

treatments due to therapeutic ultrasound. Protein OD at $450 \mathrm{~nm}$ of ligament fibroblasts.

Therapeutic ultrasound increased the OD and protein concentration of type I collagen, type III collagen, and fibronectin significantly $(* * \mathrm{P}=0.005)$ among the groups on the $6^{\text {th }}$ day. Compared to the control group on the $6^{\text {th }}$ day after the stimulation period, the low dose of ultrasound did not synthesize type I collagen or type III collagen; however, fibronectin was increased by $79 \%$. In contrast, on the $6^{\text {th }}$ day after the stimulation period, the high dose of ultrasound did not synthesize type I collagen or type III collagen, but decreased fibronectin by $100 \%$. Compared to the control group on the $10^{\text {th }}$ day after the stimulation period, the low dose of ultrasound increased the concentration of both collagens (type I collagen by 30\%; type III collagen by $33 \%$ ) but decreased fibronectin by $33 \%$. In contrast, compared to the control group on the $10^{\text {th }}$ day after the stimulation period, the high dose of ultrasound increased the concentration of the three proteins: type I collagen by $45 \%$; type III collagen by $71 \%$; and fibronectin by $44 \%$.

Accordingly, we confirmed that the high dose $\left(2.0 \mathrm{~W} / \mathrm{cm}^{2}\right)$ of therapeutic ultrasound enhances the synthesis of structural proteins, such as type I collagen, type III collagen, and adhesive proteins such as fibronectin, better than the low dose $\left(1.0 \mathrm{~W} / \mathrm{cm}^{2}\right)$ on the $10^{\text {th }}$ day after the stimulation period. A box plot shows the protein concentration data (Fig 11).

\section{Fig 11. Increase in the concentration of ECM for early and late treatments due to therapeutic}

ultrasound. Protein concentration in cell culture supernatants of ligament fibroblasts. Values were 
measured on the $6^{\text {th }}$ day and $10^{\text {th }}$ day after stimulation period for type I collagen, type III collagen, and fibronectin.

\section{Effect of therapeutic ultrasound on $\beta$-actin expression for promoting}

Through immunofluorescence imaging, $\beta$-actin (an essential structural protein of the cell cytoskeleton) was detected in both treated and control ligament fibroblasts. We found that both doses of therapeutic ultrasound decreased the elastic modulus of ligament fibroblasts, an effect caused by cytoskeleton reorganization, which was visualized for both treatments in our images through $\beta$-actin expression (Fig 12). The IHC image analysis showed a greater $\beta$-actin shortening area in the treatment groups. Compared to the control group, after the stimulation period, the low dose of ultrasound increased the mean of the $\beta$-actin shortening area by $74 \%$. In contrast, compared to the control group, after the stimulation period, the high dose of ultrasound increased the mean of the $\beta$-actin shortening area by $31 \%$. Finally, compared to the high dose after the stimulation period, the low dose of ultrasound increased the mean of the $\beta$-actin shortening area by $63 \%$. Nevertheless, there was no statistically significant difference among the groups $(\mathrm{P}=$ 0.373). This result can be explained by the small sample size for all groups $(n=3)$. Refer to the supporting information (S4 File) for additional details. 
Fig 12. Alteration of $\beta$-actin expression to promote early and late treatments due to

therapeutic ultrasound. (A) Immunofluorescence analysis of $\beta$-actin (green) and cell nuclei (blue) in ligament fibroblasts. (B) Mean of $\beta$-actin area $\left(\mathrm{cm}^{2}\right)$. Error bars indicate SEMs.

\section{Statistical analysis}

Descriptive statistics and multiple comparisons between all groups are presented in the supporting information (S4 file).

\section{Discussion}

Through a multidisciplinary approach that included an in vitro experiment and a computational simulation, our results demonstrate that conventional doses of therapeutic ultrasound applied for five days modify the mechanical and biological properties of ligament fibroblasts by altering their cytoskeleton while maintaining cell viability. More specifically, low $\left(1.0 \mathrm{~W} / \mathrm{cm}^{2}\right)$ and high $(2.0$ $\mathrm{W} / \mathrm{cm}^{2}$ ) doses promote cytoskeleton deformation, causing ligament fibroblasts to soften and triggering cell biological responses related to the early (proliferative) and late (remodeling) stages of the wound healing process. Overall, our results suggest that ligament fibroblasts reorganize their cytoskeleton as evidenced by the shortening of the $\beta$-actin area [79]. These results are manifested by the decreased elastic modulus, visible cytoskeleton displacements, and decreased harmonics in treated cells [80]. Moreover, both doses activate the dynamic role of the cytoskeleton to (i) allow cells to proliferate and migrate after applying a low dose [81], (ii) increase collagen synthesis to maintain the resistance of the ECM against the high dose [21,82] and probably restore the fluid 
volume [79], and (iii) increase the fibronectin synthesis to maintain the cell attached to the surface while collagen is synthesized in the late stage to preserve the shape and cell architecture $[21,82]$. group at $1 \mathrm{MHz}$ prove that the resistance required to deform the ligament fibroblast with the AFM tip is lower for the treated groups. As there are no studies on ligament fibroblasts that can be used to compare with our results, in epithelial and endothelial cell lines derived from human breast cancer (MCF-7) and human umbilical vein endothelial cells (HUVEC), low-intensity ultrasound stimulation for $2 \mathrm{~s}$ with a frequency of $20 \mathrm{kHz}$, applied at two intensities of 0.9 and $1.8 \mathrm{~W} / \mathrm{cm}^{2}$, produced more cell membrane permeability (sonoporation) in HUVEC cells by the cavitation effect of the ultrasound wave, which is attributed to their higher elastic modulus and lower flexibility caused by more organized actin fibers of the cytoskeleton [13].

Another study found a strong relationship between the ultrasound frequency and cell elastic modulus of breast cancer cells. At a frequency of $450 \mathrm{kHz}$ and $60 \mathrm{~s}$ exposure to ultrasound, the cell elastic modulus initially tended to increase by $50 \%$. However, when the frequencies were in the range of $550-620 \mathrm{kHz}$, the cell elastic modulus decreased by $50 \%$. The explanation of this behavior depends not only on the specific interaction between ultrasound doses that produce reorganization of the cytoskeleton but also on the cell density, size, and shape, as well as the ability of cells to detect the stiffness of the neighboring cells and surrounding location [34]. to be more deformable or flexible but possess the strength to maintain the cell shape without rupture, which can be explained by the disassemblies induced in actin microfilaments [13]. Although greater dispersion is observed, our experimental elastic modulus results (median values) are in the range of the NIH3T3 fibroblasts $(0.8-5 \mathrm{kPa})[80,83]$. This dispersion in the elastic 
findings imply that external forces produced by different intensities are a plausible reason for the increase in cell proliferation through cytoskeletal reorganization. This means that $1.0 \mathrm{~W} / \mathrm{cm}^{2}$ of ultrasound stimulates the early stage of wound healing caused by ligament fibroblasts.

Our results are consistent with those of previous studies on other mammalian cells. For example, Tsai et al. demonstrated that ultrasound enhances the migration and proliferation of tendon cells by using doses similar to those in our study [30]. Moreover, Man et al. stated that osteoblast cells exposed to the same frequency as in our study, but with different intensities and time doses, exhibit increased cell migration by $40 \%$ [87]. Aterthon et al. demonstrated that low-dose ultrasound treatment enhances the migration speed of osteoblasts (MC3T3) by 30\% [88]. Furthermore, Leng et al. showed that low-dose ultrasound treatment increases relative migration by $150 \%$ and proliferation by $80 \%$ in keratinocyte cells by activating signaling pathways [89]. Although our results have a lower percentage of increased migration than those of other studies, this difference can be explained by the different cell types chosen in the different cited investigations. Thus, we suggest that cell proliferation and migration are dependent on the dosage of ultrasound treatment. These results can be explained by cytoskeleton reorganization, as shown in other studies $[23,88]$, and by the decrease in the cell elastic modulus of the ligament fibroblasts, as demonstrated in this study.

Our findings regarding collagen synthesis on the $10^{\text {th }}$ day after stimulation are consistent with the observations of Tsai et al., who also found that low intensities of ultrasound $\left(0.1\right.$ and $\left.1.0 \mathrm{~W} / \mathrm{cm}^{2}\right)$ stimulate the synthesis of type I and type III collagen [90]. In terms of fibronectin synthesis, our results for the low dose on the $6^{\text {th }}$ day after stimulation agree with those of Harle et al., who found that fibronectin synthesis was upregulated following stimulation with lower intensities of ultrasound $\left(140 \mathrm{~mW} / \mathrm{cm}^{2}\right)$ in human osteoblasts. However, for the same low dose, but on the $10^{\text {th }}$ day after stimulation, fibronectin synthesis was diminished as shown with several low intensities 

of ultrasound $\left(140,230,540\right.$, and $\left.990 \mathrm{~mW} / \mathrm{cm}^{2}\right)$ in human periodontal ligament cells [42]. Our results showed that the synthesis of proteins depends not only on the stimulation dose but also on the number of days after stimulation, which indicates the importance of selecting the correct dose of stimulation based on the early or late stage of the ligament healing process. For example, to increase the synthesis of type I and type III collagen in the remodeling or late stage of wound healing, we recommend applying a high dose of stimulation and evaluating the results on the $10^{\text {th }}$ day after stimulation.

In addition, since collagen was not synthesized on the $6^{\text {th }}$ day after stimulation for both the treatment and control groups but was released on the $10^{\text {th }}$ day after stimulation for both doses, we confirmed that collagen production is a complex process of transcription, translation, and assembly to obtain this protein in the ECM [91]. Furthermore, these findings suggest that therapeutic ultrasound may improve the new structural and mechanical ECM of an injured ligament because collagen provides resistance to the tissue [92].

On the other hand, while fibronectin promotes cell adherence to the source surface [93], our results suggest that the low dose on the $10^{\text {th }}$ day after stimulation decreases the synthesis of fibronectin to avoid ligament fibroblast attachment; the decrease in fibronectin enables cell proliferation and migration. A high dose on the $10^{\text {th }}$ day increases the synthesis of fibronectin to enhance ligament fibroblast attachment; the increase in fibronectin facilitates synthesis of type I and type III collagen.

Moreover, we infer that the low dose of ultrasound is the treatment that primarily increased the $\beta$ actin shortening area. As shown in living fibroblasts, shortening of stress fibers occurs starting at the proximal end, which is reflected by a decrease in fluorescence intensity as measured in our study [94]. On the other hand, the high dose increased the $\beta$-actin shortening area to facilitate 
collagen and fibronectin synthesis, as we previously demonstrated [95]. To our knowledge, no evidence has been reported about the effects of ultrasound on $\beta$-actin expression in ligament fibroblasts; however, low-intensity pulsed ultrasound promotes actin assembly (polymerization) by mechanical stress in osteoblasts [96]. It is also important to mention that a high dose decreases the $\beta$-actin shortening area to allow fibroblasts to attach to the ECM and increase collagen synthesis by actin assembly [95].

We focused our attention on the mechanical properties that altered the cytoskeleton dynamics to determine the biological responses related to the wound healing process after applying low and high doses of therapeutic ultrasound on ligament fibroblasts. The elastic modulus and harmonics of the cytoskeleton, such as those observed in cancer cell mechanics, can be used as biomarkers to determine cell function because the elastic modulus is an indicator of cancer cell invasiveness [85], and the harmonics can predict scenarios of possible damage to cells as low-frequency ultrasound induces cytotoxic effects on tumor cells [7]. We propose that the elastic modulus is an indicator of actin reorganization for cell proliferation, migration, and synthesis of collagen and fibronectin after applying therapeutic ultrasound doses to ligament fibroblasts, and that harmonics can be a predictor of cell viability and cytoskeleton deformation. Our findings reveal the reasons for the relevance of the above-described interactions between the cell mechanics and biological responses of ligament fibroblasts caused by the application of therapeutic ultrasound waves.

\section{Conclusions}

Our study introduces a multidisciplinary approach for diagnosing cell function through cell mechanics analysis in ligaments and hopefully in other dense connective tissues such as the tendon, fascia, and skin. This study presents a new perspective of cell mechanics in rehabilitation, which can help researchers engaged in clinical reasoning to formulate specific doses of therapeutic 
641 ultrasound that can potentially improve the early and late stages of the ligament wound healing $642 \quad$ process.

\section{$643 \quad$ References}

644 1. Vicente-Manzanares M. Cell migration at a glance. J Cell Sci. 2005;118(21):4917-9.

645 2. Springer Nature. Cell migration. C Springer Nature Publishing; [Internet] 2019 [Cited

6462019 Nov 12]. Available from: https:/www.nature.com/subjects/cell-migration.

647 3. William E. Prentice. Understanding and Managing the Healing Process Through

648

649

650

Rehabilitation. In: Hoogenboom B, Voight M, Prentice W, editors. Musculoskeletal

Interventions: Techniques for Therapeutic Exercise. 3rd ed. New York: McGraw-Hill; 2013.

4. Nijenhuis N, Zhao X, Carisey A, Ballestrem C, Derby B. Combining AFM and acoustic probes to reveal changes in the elastic stiffness tensor of living cells. Biophys J. 2014;107(7):1502-12.

5. Nikolaev NI, Müller T, Williams DJ, Liu Y. Changes in the stiffness of human mesenchymal stem cells with the progress of cell death as measured by atomic force microscopy. Biomech. 2014;47(3):625-30.

6. Schulze KD, Zehnder SM, Urueña JM, Bhattacharjee T, Sawyer WG, Angelini TE. Elastic modulus and hydraulic permeability of MDCK monolayers. J Biomech. 2017;53:210-3.

7. Geltmeier A, Rinner B, Bade D, Meditz K, Witt R, Bicker U, et al. Characterization of dynamic behaviour of MCF7 and MCF10A cells in ultrasonic field using modal and harmonic analyses. PLoS One. 2015;10(8):1-20. 
Y-Index and Other Scientometric Indicators. Curr Sci. 2016 May 1;110(9):1823-8.

9. Miller D, Smith N, Bailey M, Czarnota G, Hynynen K, Makin I. Overview of therapeutic ultrasound applications and safety considerations. J Ultrasound Med. 2012;31(4):623-34.

10. O’Brien Jr. WD. Ultrasound-biophysics mechanisms. Prog Biophys Mol Biol. 2007 Jan;93(1-3):212-55.

11. Tole NM. Intensity of ultrasound. In: Ostensen H, editor. Basic Physics of Ultrasonographic Imaging. Malta: World health organization; 2005. p. 33-4.

12. Rodríguez M. Ultrasonidos. In: Electroterapia en Fisioterapia. 2a ed. Buenos Aires: Editorial Médica Panamericana; 2004. p. 515-51.

13. Khayamian MA, Baniassadi M, Abdolahad M. Monitoring the effect of sonoporation on the cells using electrochemical approach. Ultrason Sonochem. 2018;41:619-25.

14. Paluch EK, Nelson CM, Biais N, Fabry B, Moeller J, Pruitt BL, et al. Mechanotransduction : use the force (s). BMC Biol. 2015;13(47):1-14.

15. Tsata V, Beis D. In full force. Mechanotransduction and morphogenesis during homeostasis and tissue regeneration. J Cardiovasc Dev Dis. 2020;7(40):1-18.

16. Herrmann H, Bär H, Kreplak L, Strelkov S V, Aebi U. Intermediate filaments: from cell architecture to nanomechanics. Nat Rev Mol Cell Biol. 2007 Jul;8(7):562-73.

17. Samandari M, Abrinia K, Mokhtari-Dizaji M, Tamayol A. Ultrasound induced strain cytoskeleton rearrangement: An experimental and simulation study. J Biomech. 2017;60:39-47.

18. Allsop G, Peckham M. Cytoskeleton and Cell Motility. Compr Biotechnol Second Ed. 2011;1:191-204. 
685

686

687

688

689

690

691

692

693

694

695

696

697

698

699

700

701

702

703

704

705

706

19. Mizrahi N, Zhou EHH, Lenormand G, Krishnan R, Weihs D, Butler JP, et al. Low intensity ultrasound perturbs cytoskeleton dynamics. Soft Matter. 2012;8(8):2438-43.

20. Louw TM, Budhiraja G, Viljoen HJ, Subramanian A. Mechanotransduction of Ultrasound is Frequency Dependent Below the Cavitation Threshold. Ultrasound Med Biol. 2013;39(7):1303-19.

21. Alenghat FJ, Ingber DE. Mechanotransduction: All Signals Point to Cytoskeleton, Matrix, and Integrins. Sci STKE. 2002 Feb 12;(119):pe6.

22. Tibbitt MW, Anseth KS. Dynamic Microenvironments: The Fourth Dimension. Sci Transl Med. 2012 Nov 14;4(160):160ps24 LP-160ps24.

23. de Lucas B, Pérez LM, Bernal A, Gálvez BG. Ultrasound Therapy: Experiences and Perspectives for Regenerative Medicine. Genes (Basel). 2020;11(9):1-21.

24. Oliveira PD De, Oliveira DAAP, Martinago CC, Célia R, Frederico P, Soares CP, et al. Effect of low-intensity pulsed ultrasound therapy on a fibroblasts cell culture. Fisioter e Pesqui. 2015;22(2):112-8.

25. Bohari SP, Grover LM, Hukins DW. Pulsed low-intensity ultrasound increases proliferation and extracelluar matrix production by human dermal fibroblasts in threedimensional culture. J Tissue Eng. 2015;6:2041731415615777.

26. Bertin LD, Poli-Frederico RC, Pires Oliveira DAA, Oliveira PD, Pires FB, Silva AFS, et al. Analysis of Cell Viability and Gene Expression After Continuous Ultrasound Therapy in L929 Fibroblast Cells. Am J Phys Med Rehabil. 2019;98(5):369-72.

27. Hormozi-Moghaddam Z, Mokhtari-Dizaji M, Nilforoshzadeh MA, Bakhshandeh M. Lowintensity ultrasound to induce proliferation and collagen I expression of adipose-derived 
mesenchymal stem cells and fibroblast cells in co-culture. Meas J Int Meas Confed. 2021;167(May 2020):108280.

28. Lennart DJ. Nonthermal effects of therapeutic ultrasound: the frequency resonance hypothesis. J Athl Train. 2002 Jul;37(3):293-9.

29. Louw TM, Budhiraja G, Viljoen HJ, Subramanian A. Mechanotransduction of Ultrasound

32. Iranmanesh I, Ohlin M, Ramachandraiah H, Ye S, Russom A, Wiklund M. Acoustic micro-vortexing of fluids, particles and cells in disposable microfluidic chips. Biomed Microdevices. 2016;18(4):1-7.

33. Carmine Pappalettere IM, Tachibana K. Effect of Different Ultrasound Frequency Sweep Pattern on Leukemic Cells. In: Proceedings of the World Congress on Electrical Engineering and Computer Systems and Science (EECSS 2015). Barcelona; 2015. p. 1-2.

34. Ivone M, Lamberti L, Pappalettere C, Caratozzolo MF, Tullo A. Experimental comparison Of MCF7 And MCF10A response to low intensity ultrasound. J Mech Med Biol. 2019;19(6):1-24.

35. Conneely M, Mcgloin D, Robertson P, Mclean WHI, Campbell P a. Influence of ultrasound exposure on cell-mechanical properties : A preliminary study on MCF7 human 
breast cancer cells. In: The 15th European Microscopy Congress. Manchester Central: Journal of Microscopy; 2012.

36. Izadifar Z, Babyn P, Chapman D. Mechanical and Biological Effects of Ultrasound: A Review of Present Knowledge. Ultrasound Med Biol. 2017;43(6):1085-104.

37. Rubin D, Anderton N, Smalberger C, Polliack J, Nathan M, Postema M. On the Behaviour of Living Cells under the Influence of Ultrasound. Fluids. 2018;3(4):82.

38. Jiang YY, Park JK, Yoon HH, Choi H, Kim CW, Seo YK. Enhancing Proliferation and ECM Expression of Human ACL Fibroblasts by Sonic Vibration. Prep Biochem Biotechnol. 2015;45(5):476-90.

39. Henshaw DR, Attia E, Bhargava M, Hannafin JA. Canine ACL Fibroblast Integrin Expression and Cell Alignment in Response to Cyclic Tensile Strain in ThreeDimensional. J Orthop Res. 2006;24(3):481-90.

40. Karlsson LK, Junker JPE, Grenegård M, Kratz G. Human Dermal Fibroblasts: A Potential Cell Source for Endothelialization of Vascular Grafts. Ann Vasc Surg. 2009;23(5):66374.

41. Spitalnik P. Histology laboratory manual 2015-2016. 2015.

42. Harle J, Salih V, Mayia F, Knowles J, Olsen I. Effects of ultrasound on the growth and function of bone and periodontal ligament cells in vitro. Ultrasound Med Biol. 2001 Apr;27(4):579-86.

43. Carrer V de M, Setti JAP, Veronez D da L, Moser AD. Continuous therapeutic ultrasound in the healing process in rat skin. Fisioter em Mov. 2015;28(4):751-8.

44. Uhlemann C, Heinig B, Wollina U. Therapeutic ultrasound in lower extremity wound 
management. Int J Low Extrem Wounds. 2003 Sep;2(3):152-7.

45. Ng CO., Ng GY., See EK., Leung MC. Therapeutic ultrasound improves strength of achilles tendon repair in rats. Ultrasound Med Biol. 2003 Oct;29(10):1501-6.

46. Robertson VJ, Baker KG. A review of therapeutic ultrasound: effectiveness studies. Phys Ther. 2001;81:1339-50.

47. Warden SJ, Avin KG, Beck EM, DeWolf ME, Hagemeier MA, Martin KM. Low-intensity pulsed ultrasound accelerates and a nonsteroidal anti-inflammatory drug delays knee ligament healing. Am J Sports Med. 2006;34(7):1094-102.

48. Baker KG, Robertson VJ, Duck F a. A review of therapeutic ultrasound: biophysical effects. Vol. 81, Phys Ther. 2001. p. 1351-8.

49. Vernon MM, Lewin MB. Fetal and Neonatal Echocardiography. Avery's Dis Newborn. 2018 Jan 1;779-89.

50. Chen J. Nanobiomechanics of living cells: a review. Interface Focus. 2014;4(2):20130055-20130055.

51. Solon J, Levental I, Sengupta K, Georges PC, Janmey PA. Fibroblast adaptation and stiffness matching to soft elastic substrates. Biophys J. 2007;93(12):4453-61.

52. Guz N, Dokukin M, Kalaparthi V, Sokolov I. If Cell Mechanics Can Be Described by Elastic Modulus: Study of Different Models and Probes Used in Indentation Experiments. Biophys J. 2014;107(3):564-75.

53. Managuli V, Roy S. Asymptotical Correction to Bottom Substrate Effect Arising in AFM Indentation of Thin Samples and Adherent Cells Using Conical Tips. Exp Mech. 2018;19. 
54. Pegoraro AF, Janmey P, Weitz DA. Mechanical properties of the cytoskeleton and cells. Cold Spring Harb Perspect Biol. 2017;9(11).

55. Barreto S, Lacroix D. Quantification of CSK Mechanics and Deformation in Relation to Cellular Functioning. In: Multiscale Mechanobiology in Tissue Engineering. Singapore: Springer Singapore; 2019. p. 181-93.

56. Ingber DE. Tensegrity I . Cell structure and hierarchical systems biology. J Cell Sci. 2003;116(7):1157-73.

57. Ananthakrishnan R, Guck J, Wottawah F, Schinkinger S, Lincoln B, Romeyke M, et al. Quantifying the contribution of actin networks to the elastic strength of fibroblasts. J Theor Biol. 2006;242:502-16.

58. Alberts B, Johnson A, Lewis J. The self-assembly and dynamic structure of cytoskeletal filaments. In: Molecular Biology of the Cell. 4th ed. New York: Garland Science; 2002.

59. Hoh JH, Schoenenberger C a. Surface morphology and mechanical properties of MDCK monolayers by atomic force microscopy. J Cell Sci. 1994;107(Pt 5):1105-14.

60. Jacobs CR, Huang H, Kwon RY. Introduction to Cell Mechanics and Mechanobiology. 1st ed. New York: Garland Science; 2012. 350 p.

61. Ofek G, Wiltz DC, Athanasiou KA. Contribution of the Cytoskeleton to the Compressive Properties and Recovery Behavior of Single Cells. Biophys J. 2009;97(7):1873-82.

62. Guilak F, Haider MA, Setton LA, Laursen T, Baaijens FPT. Multiphasic models of cell mechanics Farshid. In: Mofrad MRK, Kamm RD, editors. Cytoskeletal mechanics Models and measurements. New York: Cambridge University Press; 2006. p. 256.

63. Mcgarry JG, Prendergast PJ. A three-dimensional finite element model of an adherent 
eukaryotic cell. Eur Cells Mater. 2004;7:27-34.

64. Palmer JS, Boyce MC. Constitutive modeling of the stress-strain behavior of F-actin filament networks. Acta Biomater. 2008;4:597-612.

65. Unterberger MJ, Schmoller KM, Bausch AR, Holzapfel GA. A new approach to model cross-linked actin networks: Multi-scale continuum formulation and computational analysis. J Mech Behav Biomed Mater. 2013 Jun 1;22:95-114.

66. Hoyle NP, Seinkmane E, Putker M, Feeney KA, Krogager TP, Chesham JE, et al. Circadian actin dynamics drive rhythmic fibroblast mobilization during wound healing. Sci Transl Med. 2017 Nov 8;9(415):1-10.

67. Chen T, Wu C, Tang M, Huang J, Su F. Complexity of the Tensegrity Structure for Dynamic Energy and Force Distribution of Cytoskeleton during Cell Spreading. PLoS One. 2010;5(12):1-11.

68. Span LFR, Pennings AHM, Vierwinden G, Boezeman JBM, Raymakers RAP, de Witte T. The dynamic process of apoptosis analyzed by flow cytometry using AnnexinV/propidium iodide and a modified in situ end labeling technique. Cytometry. 2002;47(1):24-31.

69. Hingorani R, Deng J, Elia J, McIntyre C, Mittar D. Detection of Apoptosis Using the BD Annexin V FITC Assay on the BD FACSVerse ${ }^{\mathrm{TM}}$ System. BD Biosciences. 2011.

70. Capasso JM, Cossío BR, Berl T, Rivard CJ, Jiménez C. A colorimetric assay for determination of cell viability in algal cultures. Biomol Eng. 2003 Jul 1;20(4-6):133-8.

71. Yadav K, Singhal N, Rishi V, Yadav H. Cell Proliferation Assays. eLS John Wiley Sons, Ltd Chichester. 2014; 
72. Kuete V, Karaosmanoğlu O, Sivas H. Anticancer Activities of African Medicinal Spices and Vegetables. In: Medicinal Spices and Vegetables from Africa: Therapeutic Potential Against Metabolic, Inflammatory, Infectious and Systemic Diseases. Elsevier Inc.; 2017. p. 271-97.

73. McGowan EM, Alling N, Jackson EA, Yagoub D, Haass NK, Allen JD, et al. Evaluation of cell cycle arrest in estrogen responsive MCF-7 breast cancer cells: Pitfalls of the MTS assay. PLoS One. 2011;6(6):1-8.

74. Liang C-C, Park AY, Guan J-L. In vitro scratch assay: a convenient and inexpensive method for analysis of cell migration in vitro. Nat Protoc. 2007;2(2):329-33.

75. Gay S, Vijanto J, Raekallio J, Penttinen R. Collagen types in early phases of wound healing in children - PubMed. Acta Chir Scand. 1978;144(4):205-11.

76. Xue M, Jackson CJ. Extracellular Matrix Reorganization During Wound Healing and Its Impact on Abnormal Scarring. Adv Wound Care. 2015;4(3):119-36.

77. Dugina V, Zwaenepoel I, Gabbiani G, Clement S, Chaponnier C. $\beta$ - and $\gamma$-Cytoplasmic Actins Display Distinct Distribution and Functional Diversity. J Cell Sci. 2009;122(16):2980-8.

78. Abercrombie M. Fibroblasts. J Clin Pathol. 1978;12:1-6.

79. Langevin HM, Nedergaard M, Howe AK. Cellular control of connective tissue matrix tension. J Cell Biochem. 2013;114(8):1714-9.

80. Pastrana HF, Cartagena-Rivera AX, Raman A, Ávila A. Evaluation of the elastic Young's modulus and cytotoxicity variations in fibroblasts exposed to carbon-based nanomaterials. J Nanobiotechnology. 2019;17(1):1-15. 
81. Tavares S, Vieira AF, Taubenberger AV, Araújo M, Martins NP, Brás-Pereira C, et al. Actin stress fiber organization promotes cell stiffening and proliferation of pre-invasive breast cancer cells. Nat Commun. 2017;8(15237).

82. Hurtley SM. Cell Biology of the Cytoskeleton. Science (80- ). 1998;279(5350):459.

83. Efremov YM, Shpichka AI, Kotova SL, Timashev PS. Viscoelastic mapping of cells based on fast force volume and PeakForce Tapping. Soft Matter. 2019;15(27):5455-63.

84. Jaganathan, Saravana Kumar Subramanian AP, Vellayappan MV, Balaji A, Aruna John A, Jaganathan AK, Supriyanto E. Natural frequency of cancer cells as a starting point in cancer treatment. Curr Sci. 2016;110(9):1828-32.

85. Azadi S, Tafazzoli-Shadpour M, Soleimani M, Warkiani ME. Modulating cancer cell mechanics and actin cytoskeleton structure by chemical and mechanical stimulations. J Biomed Mater Res - Part A. 2019;107(8):1569-81.

86. Doan N, Reher P, Meghji S, Harris M. In vitro effects of therapeutic ultrasound on cell proliferation, protein synthesis, and cytokine production by human fibroblasts, osteoblasts, and monocytes. J Oral Maxillofac Surg. 1999 Apr;57(4):409-19.

87. Man J, Shelton RM, Cooper PR, Landini G, Scheven B a. Low intensity ultrasound stimulates osteoblast migration at different frequencies. J Bone Miner Metab. 2012 Sep;30(5):602-7.

88. Atherton P, Lausecker F, Harrison A, Ballestrem C. Low-intensity pulsed ultrasound promotes cell motility through vinculin-controlled Rac1 GTPase activity. J Cell Sci. 2017;130(14):2277-91.

89. Leng X, Shang J, Gao D, Wu J. Low-intensity pulsed ultrasound promotes proliferation 
and migration of HaCaT keratinocytes through the PI3K / AKT and JNK pathways.

Brazilian J Med Biol Res. 2018;51(12):1-8.

90. Tsai W-C, Pang J-HS, Hsu C-C, Chu N-K, Lin M-S, Hu C-F. Ultrasound Stimulation of Types I and III Collagen Expression of Tendon Cell and Upregulation of Transforming Growth Factor b. J Orthop Res. 2006;24:1310-6.

91. Kuivaniemi H, Tromp G. Type III collagen (COL3A1): Gene and protein structure, tissue distribution, and associated diseases. Gene. 2020;707:151-71.

92. Makareeva E, Leikin S. Collagen Structure, Folding and Function. Osteogenesis Imperfecta: A Translational Approach to Brittle Bone Disease. Elsevier Inc.; 2013. 71-84 p.

93. Parisi L, Toffoli A, Ghezzi B, Mozzoni B, Lumetti S, Macaluso GM. A glance on the role of fibronectin in controlling cell response at biomaterial interface. Jpn Dent Sci Rev. 2020;56(1):50-5.

94. Wang YL. Reorganization of actin filament bundles in living fibroblasts. J Cell Biol. 1984;99(4 I):1478-85.

95. Qin Z, Fisher GJ, Voorhees JJ, Quan T. Actin cytoskeleton assembly regulates collagen production via TGF- $\beta$ type II receptor in human skin fibroblasts. J Cell Mol Med. 2018;22(9):4085-96.

96. Nishida T, Kubota S, Aoyama E, Yamanaka N, Lyons KM, Takigawa M. Low-intensity pulsed ultrasound (LIPUS) treatment of cultured chondrocytes stimulates production of $\mathrm{CCN}$ family protein 2 (CCN2), a protein involved in the regeneration of articular cartilage: mechanism underlying this stimulation. Osteoarthr Cartil. 2017;25(5):759-69. 
bioRxiv preprint doi: https://doi.org/10.1101/2021.11.22.469508; this version posted November 22, 2021. The copyright holder for this preprint (which was not certified by peer review) is the author/funder, who has granted bioRxiv a license to display the preprint in perpetuity. It is made available under aCC-BY 4.0 International license.

883 


\section{Author Contributions}

The contributions made by each author to the manuscript are presented in Table 3.

Table 3. Contributions made by each author to the manuscript.

\begin{tabular}{|c|c|c|c|c|c|c|c|}
\hline & $\begin{array}{l}\text { Elastic } \\
\text { modulus }\end{array}$ & Harmonics & $\begin{array}{l}\text { Cell } \\
\text { viability }\end{array}$ & $\begin{array}{l}\text { Cell } \\
\text { proliferation }\end{array}$ & $\begin{array}{l}\text { Cell } \\
\text { migration }\end{array}$ & $\begin{array}{l}\text { ECM } \\
\text { synthesis }\end{array}$ & $\begin{array}{l}\beta \text {-actin } \\
\text { expression }\end{array}$ \\
\hline Conceptualization & $\begin{array}{l}(\mathrm{CS}), \\
(\mathrm{PR}), \\
(\mathrm{AB}), \\
(\mathrm{RM}), \\
(\mathrm{GA})\end{array}$ & $\begin{array}{l}\text { (CS), (RM), } \\
\text { (GA) }\end{array}$ & $(\mathrm{CS})$ & (CS) & $\begin{array}{l}(\mathrm{CS}) \\
(\mathrm{OM})\end{array}$ & $\begin{array}{l}(\mathrm{CS}), \\
(\mathrm{NJ})\end{array}$ & $\begin{array}{l}(\mathrm{CS}), \\
(\mathrm{OM})\end{array}$ \\
\hline $\begin{array}{l}\text { Data curation } \\
\text { Formal analysis } \\
\text { Investigation } \\
\text { Methodology }\end{array}$ & $(\mathrm{CS}),(\mathrm{PR})$ & $\begin{array}{l}(\mathrm{CS}), \\
(\mathrm{RM}),(\mathrm{GA})\end{array}$ & (CS) & (CS) & $\begin{array}{l}(\mathrm{CS}), \\
(\mathrm{OM})\end{array}$ & $\begin{array}{l}(\mathrm{CS}), \\
(\mathrm{NJ})\end{array}$ & $\begin{array}{l}\mathrm{CS}), \\
(\mathrm{OM})\end{array}$ \\
\hline $\begin{array}{l}\text { Funding } \\
\text { acquisition }\end{array}$ & $\begin{array}{l}(\mathrm{CS}), \\
(\mathrm{PR}), \\
(\mathrm{AB}), \\
(\mathrm{GA})\end{array}$ & (CS), (GA) & $\begin{array}{l}\text { (CS), } \\
(\mathrm{GA})\end{array}$ & (CS), (GA) & $\begin{array}{l}\text { (CS), } \\
(\mathrm{OM}), \\
(\mathrm{GA})\end{array}$ & $\begin{array}{l}(\mathrm{CS}), \\
(\mathrm{NJ}), \\
(\mathrm{GA})\end{array}$ & $\begin{array}{l}\text { (CS), } \\
(\mathrm{OM}), \\
(\mathrm{GA})\end{array}$ \\
\hline $\begin{array}{l}\text { Project } \\
\text { administration }\end{array}$ & $\begin{array}{l}\text { (CS), } \\
(\mathrm{GA})\end{array}$ & $(\mathrm{CS}),(\mathrm{GA})$ & $\begin{array}{l}\text { (CS), } \\
(\mathrm{GA})\end{array}$ & (CS), (GA) & $\begin{array}{l}\text { (CS), } \\
\text { (GA) }\end{array}$ & $\begin{array}{l}\text { (CS), } \\
\text { (GA) }\end{array}$ & $\begin{array}{l}(\mathrm{CS}), \\
(\mathrm{GA})\end{array}$ \\
\hline $\begin{array}{l}\text { Resources } \\
\text { Software }\end{array}$ & $\begin{array}{l}(\mathrm{CS}), \\
(\mathrm{PR}), \\
(\mathrm{AB}), \\
(\mathrm{GA})\end{array}$ & (CS), (GA) & $\begin{array}{l}\text { (CS), } \\
(\mathrm{GA})\end{array}$ & (CS), (GA) & $\begin{array}{l}(\mathrm{CS}), \\
(\mathrm{OM}), \\
(\mathrm{GA})\end{array}$ & $\begin{array}{l}(\mathrm{CS}), \\
(\mathrm{NJ}), \\
(\mathrm{GA})\end{array}$ & $\begin{array}{l}\text { (CS), } \\
(\mathrm{OM}), \\
(\mathrm{GA})\end{array}$ \\
\hline Supervision & $\begin{array}{l}\text { (AB), } \\
(\mathrm{GA}), \\
(\mathrm{RM})\end{array}$ & $\begin{array}{l}\text { (AB), (GA), } \\
(\mathrm{RM})\end{array}$ & $\begin{array}{l}\text { (AB), } \\
(\mathrm{GA})\end{array}$ & (AB), (GA) & $\begin{array}{l}(\mathrm{AB}), \\
(\mathrm{GA}), \\
(\mathrm{OM})\end{array}$ & $\begin{array}{l}(\mathrm{AB}), \\
(\mathrm{GA}), \\
(\mathrm{NJ})\end{array}$ & $\begin{array}{l}\text { (AB), } \\
(\mathrm{GA}), \\
(\mathrm{OM})\end{array}$ \\
\hline
\end{tabular}




\begin{tabular}{|c|c|c|c|c|c|c|c|}
\hline Validation & $\begin{array}{l}(\mathrm{CS}), \\
(\mathrm{PR}), \\
(\mathrm{AB}), \\
(\mathrm{RM}), \\
(\mathrm{GA})\end{array}$ & $\begin{array}{l}\text { (CS), (AB), } \\
(\mathrm{RM}),(\mathrm{GA})\end{array}$ & $\begin{array}{l}(\mathrm{AB}), \\
(\mathrm{GA})\end{array}$ & $(\mathrm{AB}),(\mathrm{GA})$ & $\begin{array}{l}(\mathrm{AB}), \\
(\mathrm{GA}), \\
(\mathrm{OM})\end{array}$ & $\begin{array}{l}(\mathrm{AB}), \\
(\mathrm{GA}), \\
(\mathrm{NJ})\end{array}$ & $\begin{array}{l}(\mathrm{AB}), \\
(\mathrm{GA}), \\
(\mathrm{OM})\end{array}$ \\
\hline Visualization & (CS), (PR) & $\begin{array}{l}\text { (CS), (RM), } \\
(\mathrm{GA})\end{array}$ & $(\mathrm{CS})$ & $(\mathrm{CS})$ & $\begin{array}{l}\text { (CS), } \\
(\mathrm{OM})\end{array}$ & $\begin{array}{l}(\mathrm{CS}), \\
(\mathrm{NJ})\end{array}$ & $\begin{array}{l}\mathrm{CS}), \\
(\mathrm{OM})\end{array}$ \\
\hline $\begin{array}{l}\text { Writing - original } \\
\text { draft }\end{array}$ & $\begin{array}{l}(\mathrm{CS}),(\mathrm{PR}) \\
\end{array}$ & $(\mathrm{CS})$ & (CS) & $(\mathrm{CS})$ & (CS) & $(\mathrm{CS})$ & $(\mathrm{CS})$ \\
\hline $\begin{array}{l}\text { Writing - review } \\
\text { \& editing }\end{array}$ & $\begin{array}{l}(\mathrm{AB}), \\
(\mathrm{GA}), \\
(\mathrm{RM})\end{array}$ & $\begin{array}{l}\text { (CS), (AB), } \\
(\mathrm{RM}),(\mathrm{GA})\end{array}$ & $\begin{array}{l}(\mathrm{CS}), \\
(\mathrm{OM}), \\
(\mathrm{AB}), \\
(\mathrm{GA})\end{array}$ & $\begin{array}{l}\text { (CS), (OM), } \\
(\mathrm{AB}),(\mathrm{GA})\end{array}$ & $\begin{array}{l}\mathrm{CS}), \\
(\mathrm{OM}), \\
(\mathrm{AB}), \\
(\mathrm{GA})\end{array}$ & $\begin{array}{l}(\mathrm{CS}), \\
(\mathrm{NJ}), \\
(\mathrm{AB}), \\
(\mathrm{GA})\end{array}$ & $\begin{array}{l}\text { (CS), } \\
(\mathrm{OM}), \\
(\mathrm{AB}), \\
(\mathrm{GA})\end{array}$ \\
\hline
\end{tabular}

aAuthor A: Cárdenas-Sandoval (CS)

bAuthor B: Pastrana-Rendón(PR)

cAuthor C: Ávila-Bernal (AB)

dAuthor D: Ramírez-Martínez (RM)

eAuthor E: Navarrete-Jimenez(NJ)

${ }^{\mathrm{f}}$ Author F: Ondo-Mendez (OM)

\section{Conflict of interest}

The authors report no conflicts of interest. 


\section{$899 \quad$ Supporting information}

$900 \quad$ S1 File: Correction of elastic modulus using the asymptotical correction mode

S2 File: Example of shortening area of $\beta$-actin analysis using immunohistochemistry (IHC)

902

903

904

905
S3 Movies (A-C): Animations of displacements and harmonics of the natural frequency of vibration $\left(50^{\text {th }}\right)$ for all groups

S4 File: Descriptive statistics and multiple comparisons between all groups

S5 File: Python script to create an octahedron tensegrity structure in Abaqus CAE for all groups 


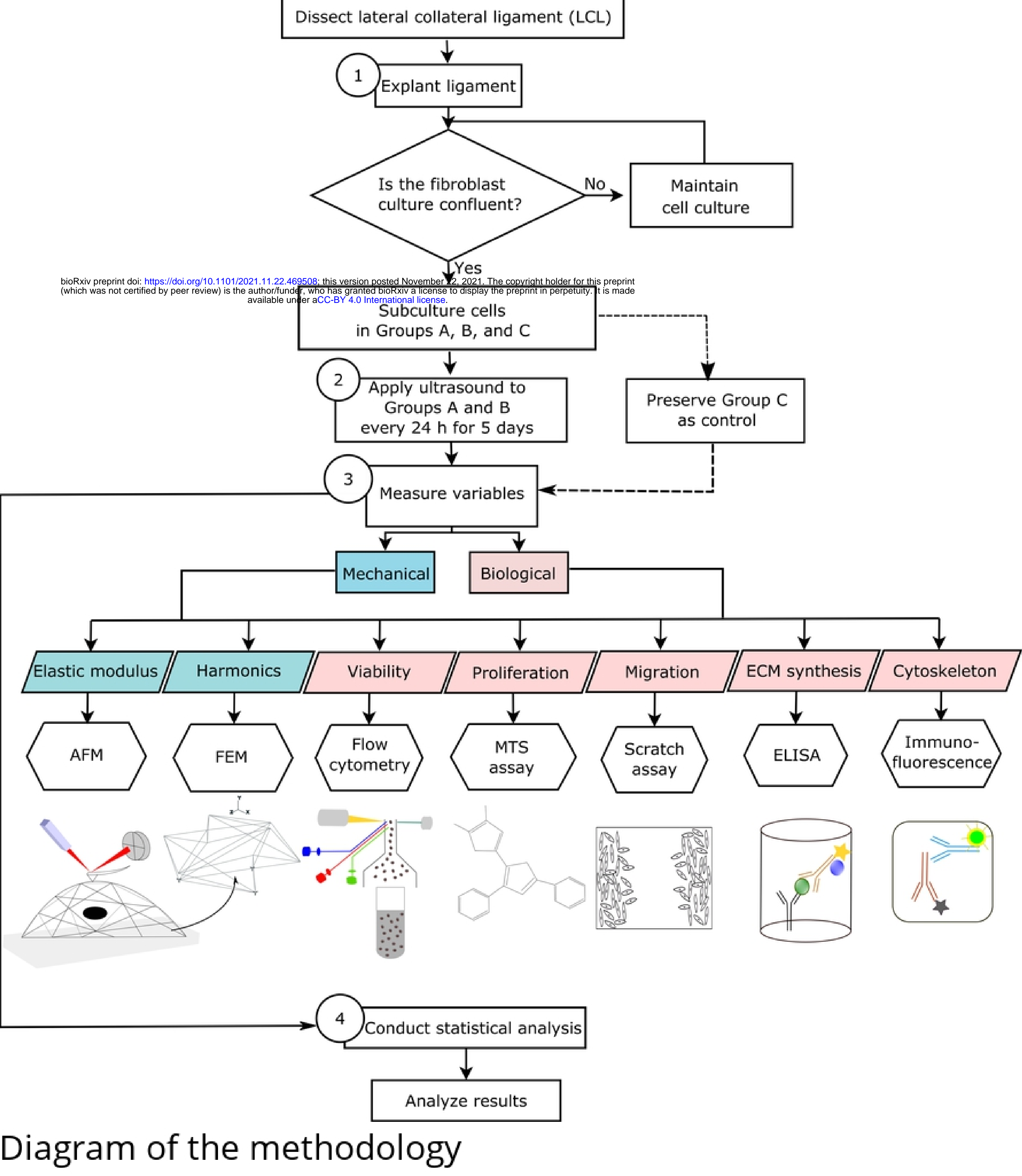


(A)

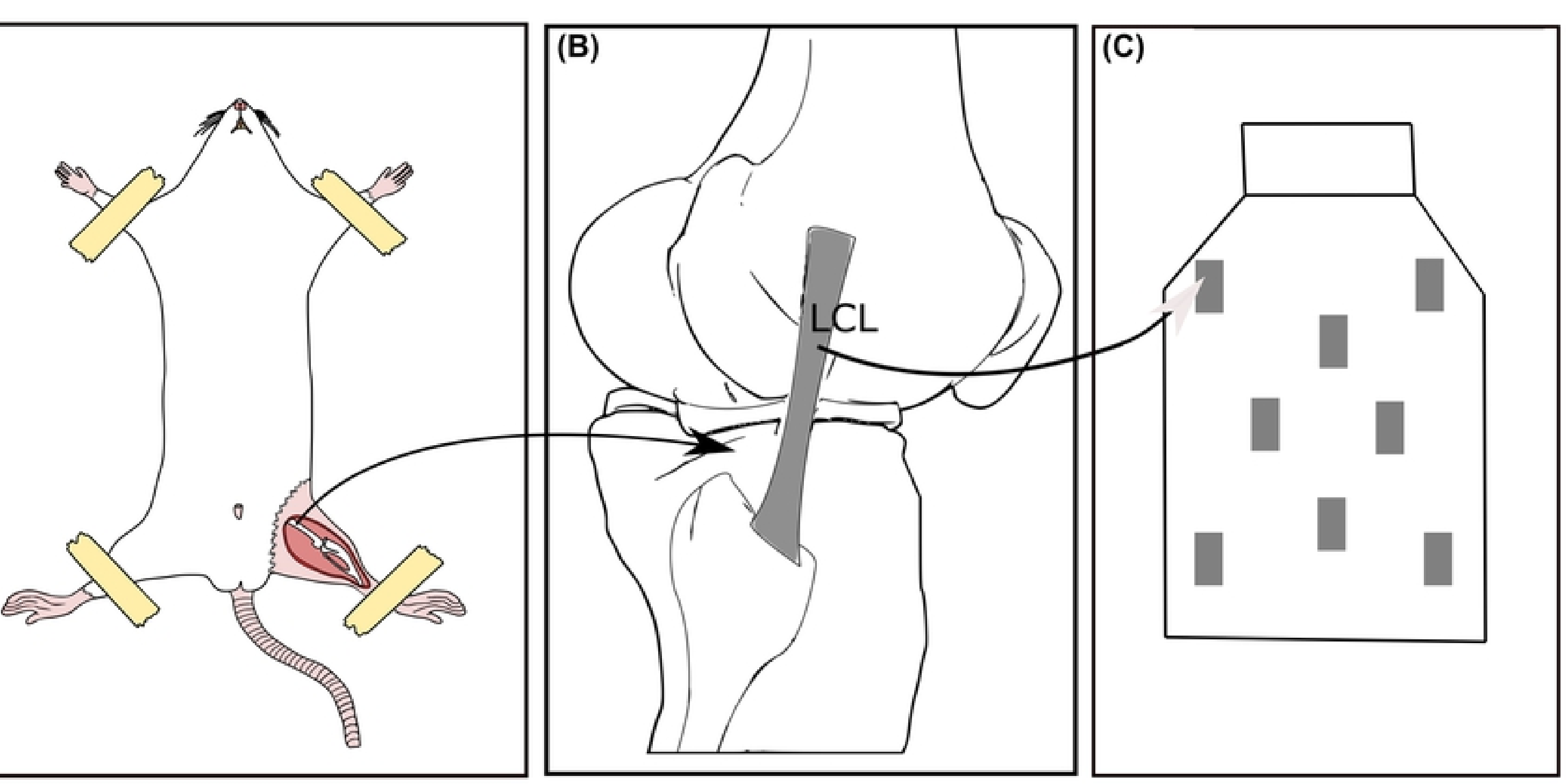

Ligament fibroblast explant 


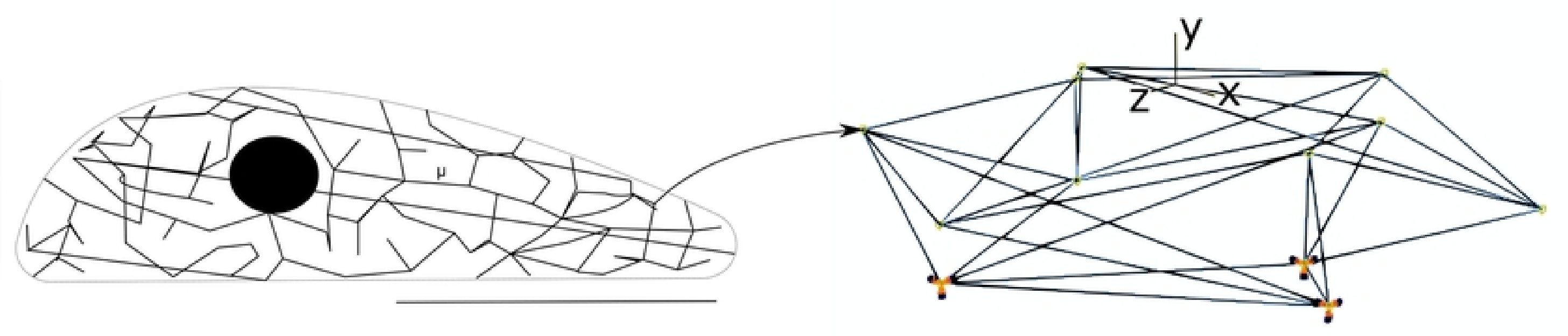

Length contact radius

Tensegrity structure

Three-dimensional octahedron tensegrity model 


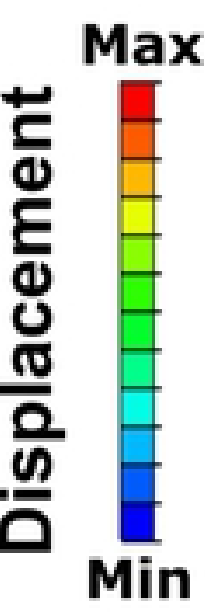

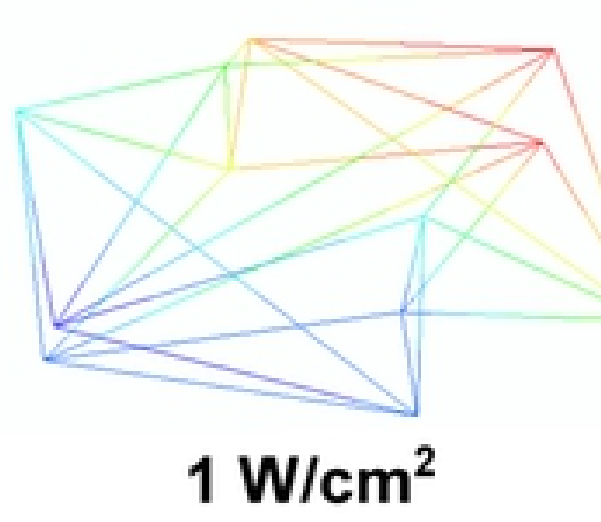

5th eigenform
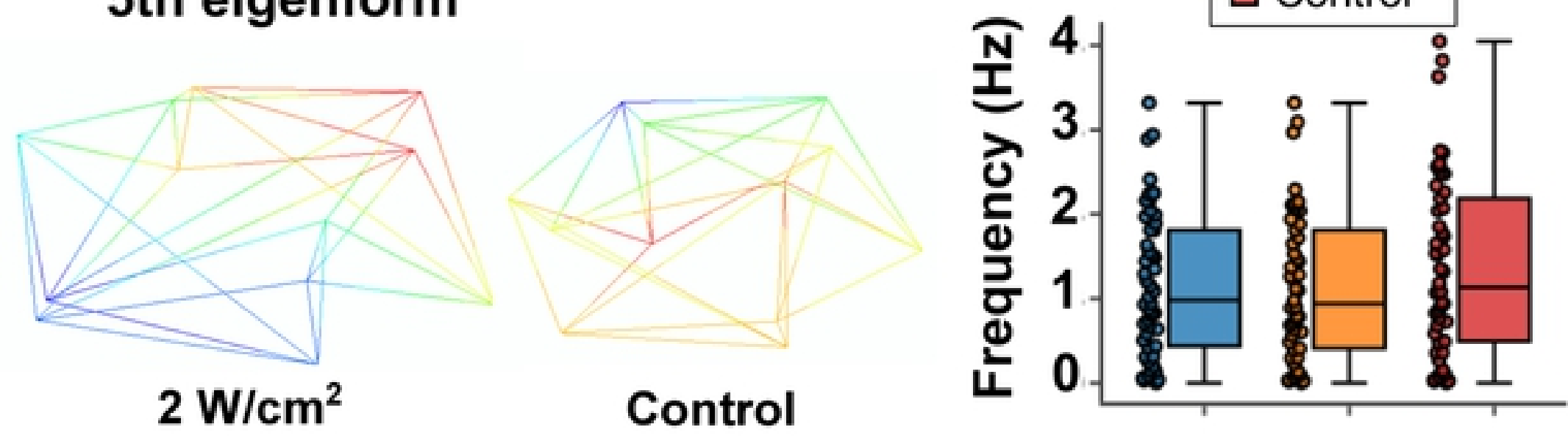

Alteration of ligament fibroblast cytoskeleton due to ultrasound 


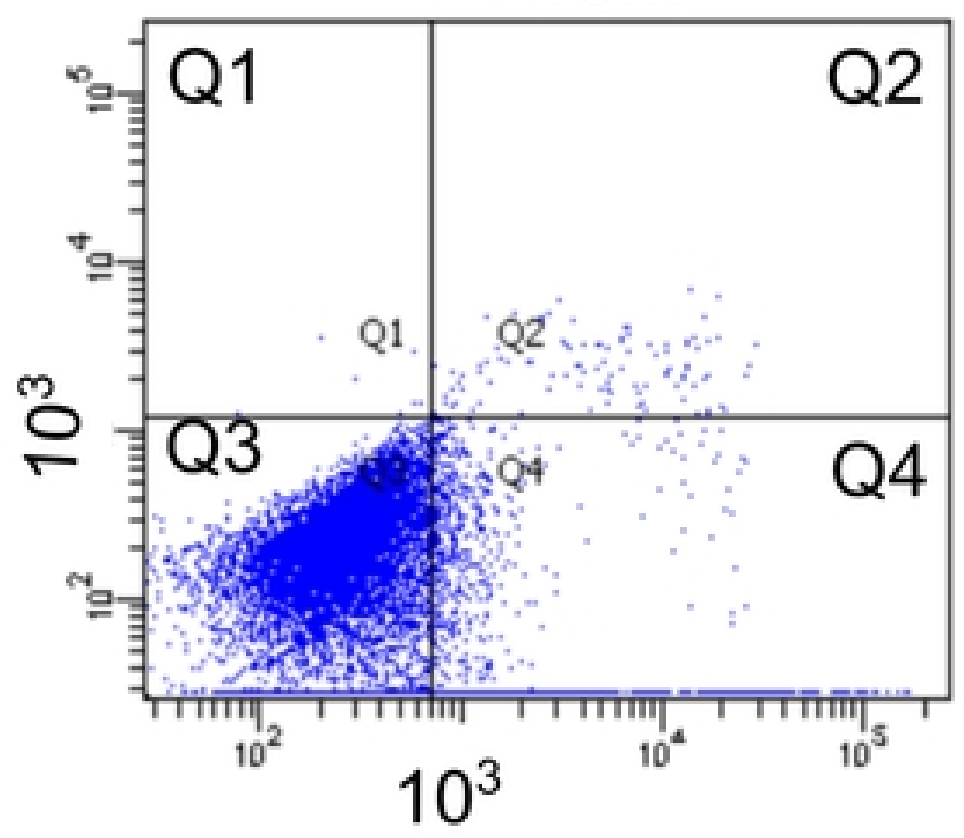

(B)

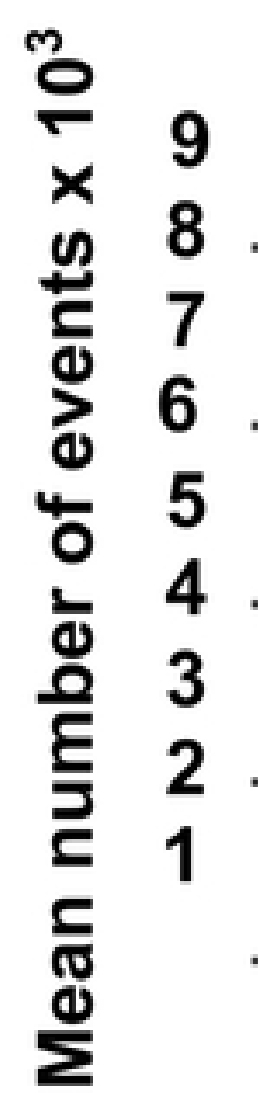

Necrotic $0.2 \% 0.1 \% 0.1 \%$

Q1

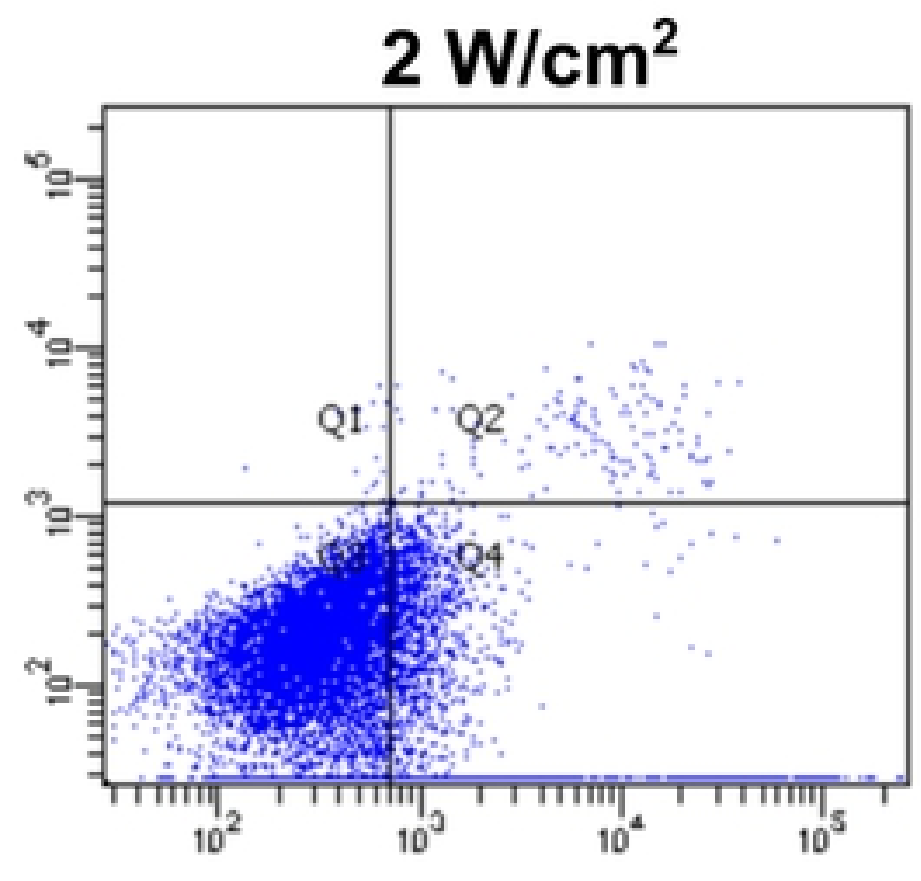

FITC-A
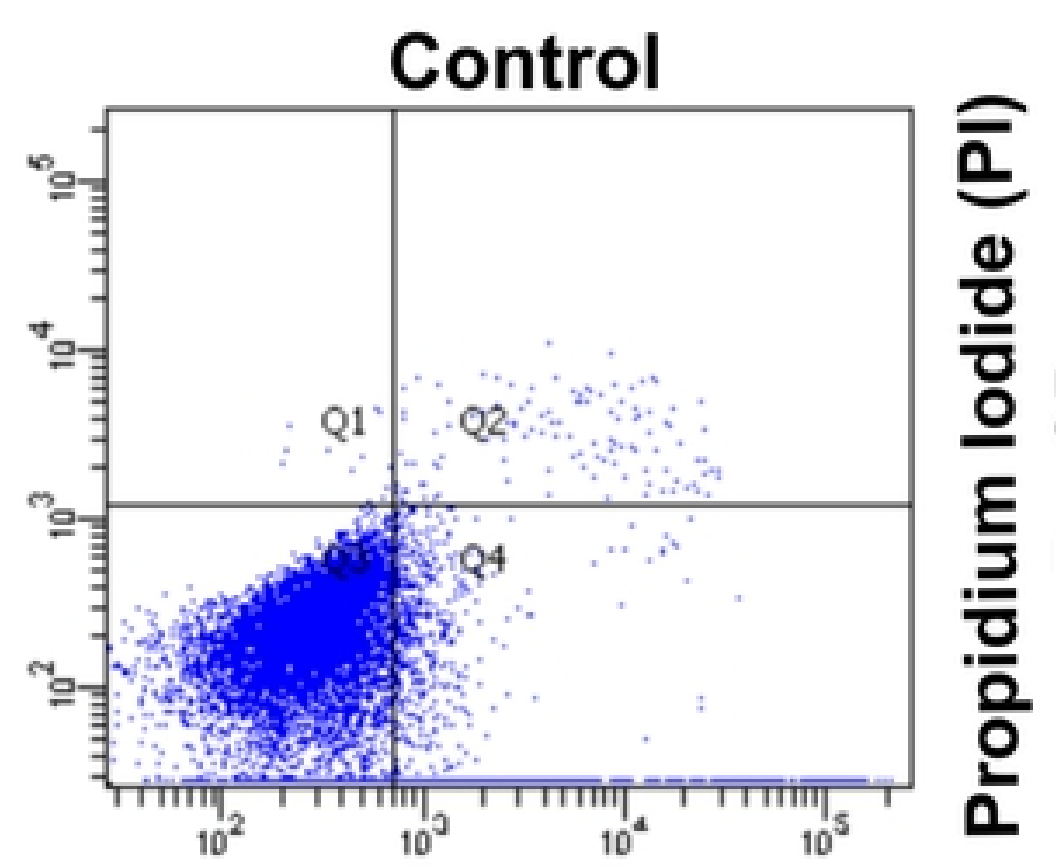

Late apoptosis $1.9 \% 0.9 \% 0.7 \%$

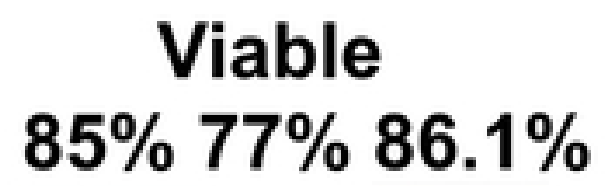

Q2

Q3

Q4

Early Apoptosis $13 \% 22.1 \% 13.1 \%$

Negligible effect of low and high doses of ultrasound on viability 
ذة

$1 \mathrm{~W} / \mathrm{cm}^{2}$

$2 \mathrm{~W} / \mathrm{cm}^{2}$

Control

(B)
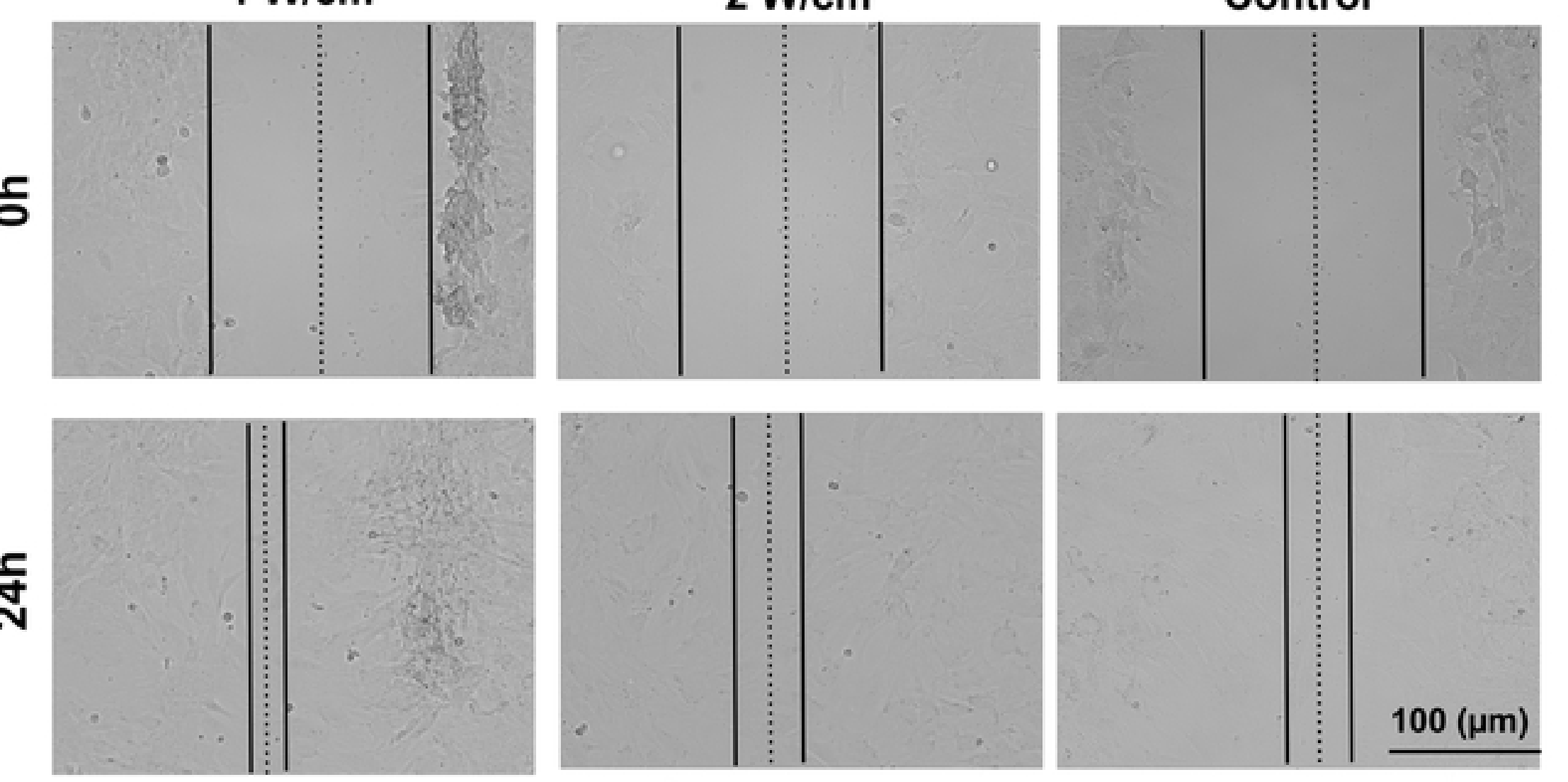

(B)
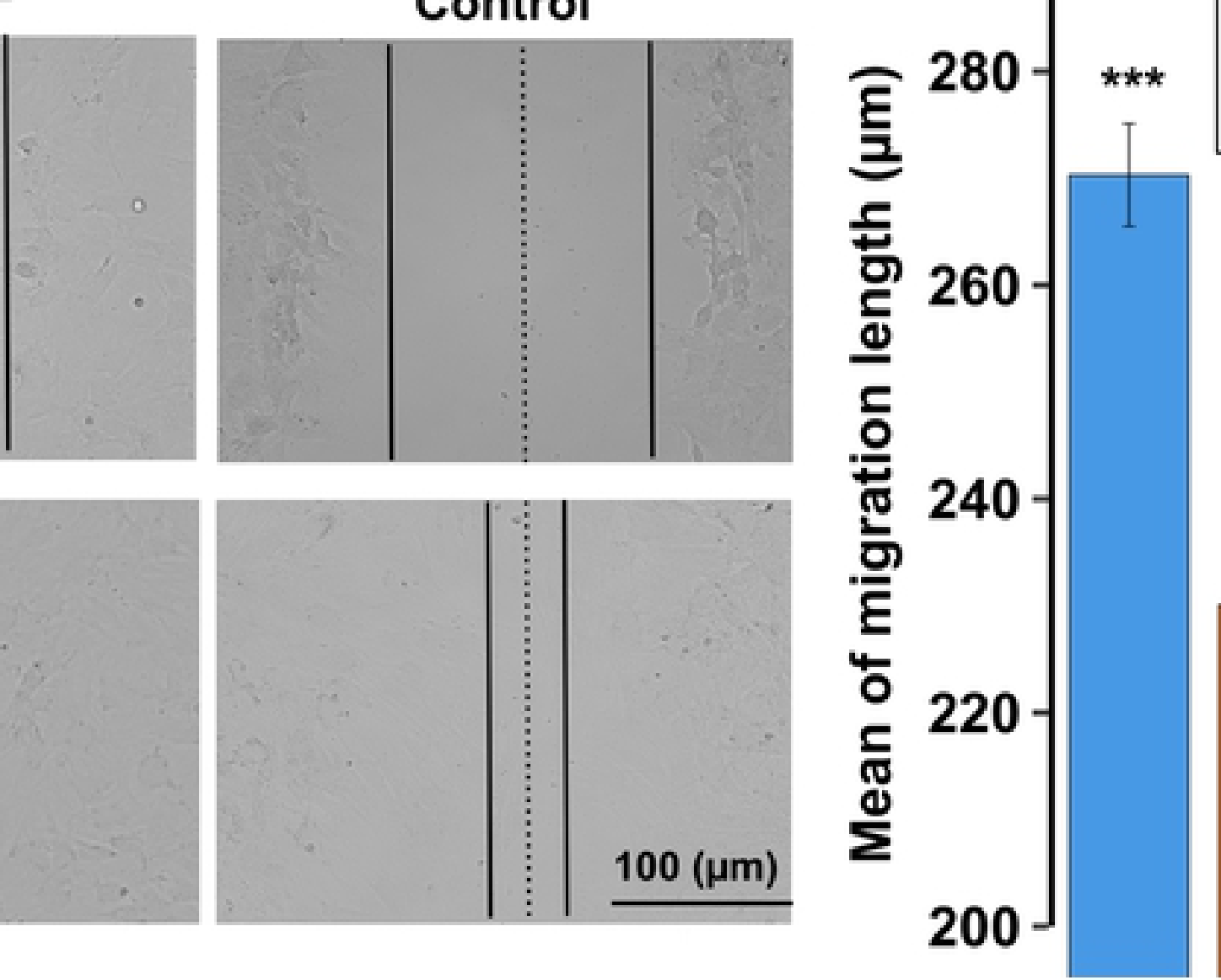

Ef fibroblast cell migration in e 


\section{$\square 1 \mathrm{~W} / \mathrm{cm}^{2}$ \\ $2 \mathrm{~W} / \mathrm{cm}^{2}$ \\ $\square$ Control \\ $\square 1 \mathrm{~W} / \mathrm{cm}^{2}$ \\ $2 \mathrm{~W} / \mathrm{cm}^{2}$ \\ $\square$ Control}

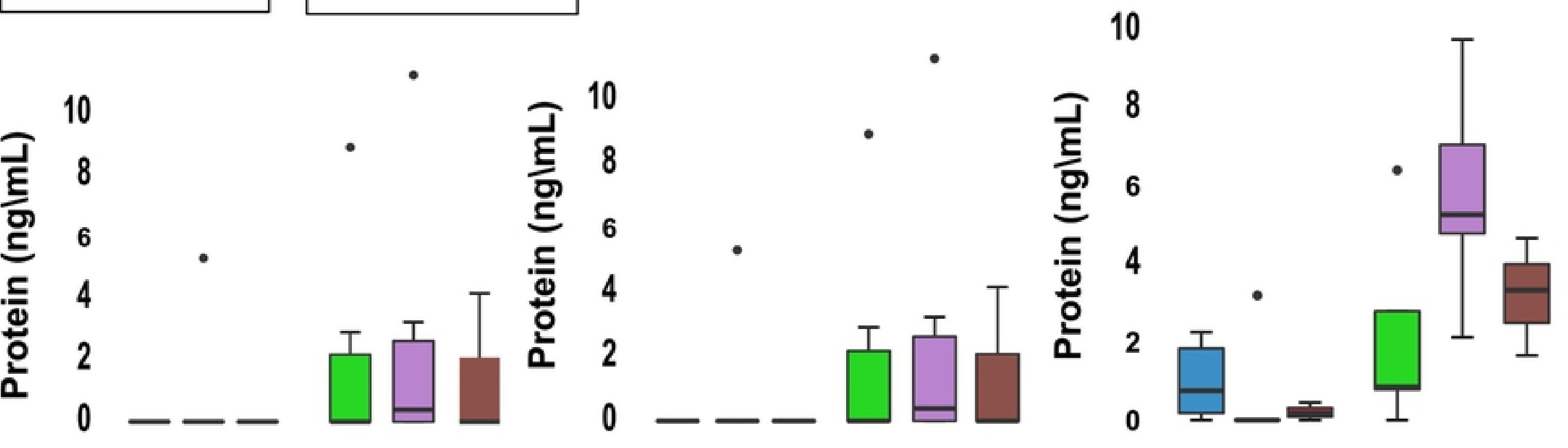

Type I collagen

Type III collagen

Fibronectin

Increase in the concentration of ECM for early and late treatmer 


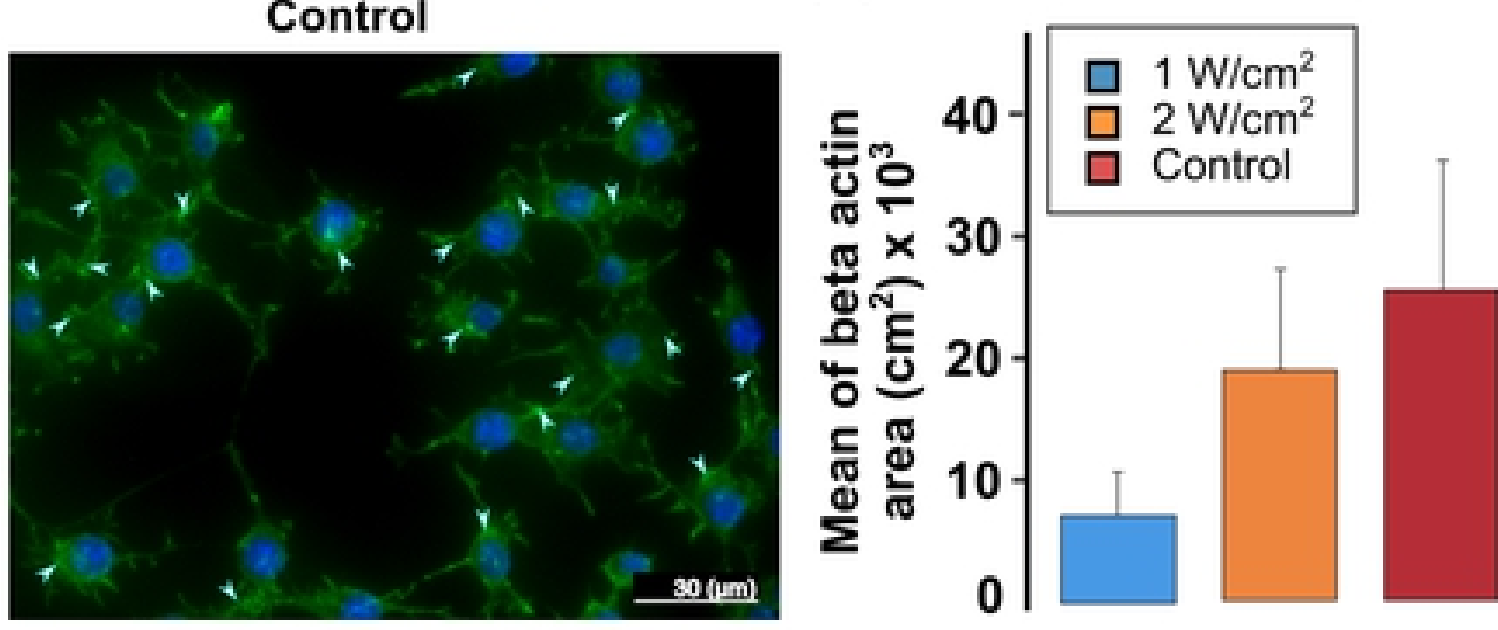

Alteration of $\beta$-actin expression to promote early and late treatr 